\title{
Seasonal productivity dynamics in the pelagic central Benguela System inferred from the flux of carbonate and silicate organisms
}

Article in Journal of Marine Systems · November 2002

DOI: 10.1016/S0924-7963(02)00189-6 · Source: OAI

\section{CITATIONS}

77

6 authors, including:

Oscar E. Romero

Universität Bremen

226 PUBLICATIONS 4,000 CITATIONS

SEE PROFILE

B. Donner

Universität Bremen

69 PUBLICATIONS 2,198 CITATIONS

SEE PROFILE
Babette Boeckel

Universität Bremen

53 PUBLICATIONS 1,240 CITATIONS

SEE PROFILE

Gaute Lavik

Max Planck Institute for Marine Microbiology

333 PUBLICATIONS 9,543 CITATIONS

SEE PROFILE

Some of the authors of this publication are also working on these related projects:

Late Pleistocene variations of the diatom productivity in the high-latitude Atlantic: convergence shifts, nutrient availability, and rapid climate variability View project

Seasonal and multiyear variability of fluxes in the Mauritanian coastal upwelling (NW Africa) View project 


\title{
Seasonal productivity dynamics in the pelagic central Benguela System inferred from the flux of carbonate and silicate organisms
}

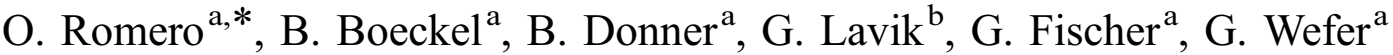 \\ ${ }^{a}$ Department of Geosciences, Universität Bremen, PO Box 3304 40, 28334 Bremen, Germany \\ ${ }^{\mathrm{b}}$ Max-Planck-Institute for Marine Microbiology, Celsiusstraße 1, 28359 Bremen, Germany
}

Received 20 June 2001; accepted 14 June 2002

\begin{abstract}
Flux of bulk components, carbonate- and silicate-bearing skeleton organisms, and the $\delta^{15} \mathrm{~N}$-isotopic signal were investigated on a 1-year time-series sediment trap deployed at the pelagic NU mooring site (Namibia Upwelling, ca. $29^{\circ} \mathrm{S}, 13^{\circ} \mathrm{E}$ ) in the central Benguela System. The flux of bulk components mostly shows bimodal seasonality with major peaks in austral summer and winter, and moderate to low export in austral fall and spring. The calcium carbonate fraction dominates the export of particulates throughout the year, followed by lithogenic and biogenic opal. Planktonic foraminifera and coccolithophorids are major components of the carbonate fraction, while diatoms clearly dominate the biogenic opal fraction. Bulk $\delta^{15} \mathrm{~N}$ isotopic composition of particulate matter is positively correlated with the total mass flux during summer and fall, while negatively correlated during winter and spring. Seasonal changes in the intensity of the main oceanographic processes affecting the NU site are inferred from variations in bulk component flux, and in the flux and diversity patterns of individual species or group of species. Influence from the Namaqua (Hondeklip) upwelling cell through offshore migration of chlorophyll filaments is stronger in summer, while the winter flux maximum seems to reflect mainly in situ production, with less influence from the coastal and shelf upwelling areas. On a yearly basis, dominant microorganisms correspond well with the flora and fauna of tropical/ subtropical waters, with minor contribution of near-shore organisms. The simultaneous occurrence of species with different ecological affinities mirrors the fact that the mooring site was located in a transitional region with large hydrographic variability over short-time intervals.
\end{abstract}

(C) 2002 Elsevier Science B.V. All rights reserved.

Keywords: Coccolithophorids; Diatoms; Foraminifera; Particle flux; Upwelling; Southern Africa; Benguela System

\section{Introduction}

The Benguela Upwelling System (BUS), one of the major Eastern Boundary Current Systems, has been the focus in the last two decades of a series of intensive oceanographic surveys aiming to the understanding of

* Corresponding author. Fax: +49-421-218-8916.

E-mail address: oromero@uni-bremen.de (O. Romero). its complex present-day characteristics. A number of instructive overviews summarizes the present knowledge on the area, and delivers a reliable picture of the main processes and mechanisms affecting its productivity dynamics (Shannon, 1985; Lutjeharms and Stockton, 1987; Lutjeharms et al., 1991; Shannon and Nelson, 1996). More recently, time-series sediment trap experiments have also contributed to the comprehension of mechanisms controlling the seasonal pro- 
duction in the water column and the export of particulates to the seafloor. Wefer and Fischer (1993) and Fischer and Wefer (1996) presented the first results on the particle dynamics at a mesotrophic trap site off Northern Namibia (Walvis Ridge) between 1988 and 1991. These authors show that the seasonality was clearly expressed by a distinct bimodal pattern in the flux of the bulk biogenic components, lately also demonstrated for coccolithophorids (Čepek, 1996; Baumann et al., 1999), siliceous phytoplankton (Treppke et al., 1996) and the $\delta^{15} \mathrm{~N}$ signal (Holmes et al., 1999, 2002). Comparatively less attention has been paid to the dynamics of the particulate material in the central and southern areas of the BUS. In a recent contribution, Giraudeau et al. (2000) evaluated the shortterm response of biogenic production to rapid changes in the coastal upwelling process at the shelf edge off Walvis Bay $\left(23^{\circ} \mathrm{S}\right)$, and proposed a highly partitioned, three-dimensional model in order to explain the process affecting the production of biogenic particles.

As in other Eastern Boundary Current systems, offshore-streaming chlorophyll filaments play a key role in the seaward transport of nutrients, particulate material and organisms from the coastal area into the pelagial realm of the BUS (e.g. Lutjeharms and Stockton, 1987; Shannon and Nelson, 1996). Additionally, these filaments greatly extend the area of high productivity associated with coastal upwelling by rapidly advecting cold, nutrient-rich waters into the mesooligotrophic open ocean. Impact of filaments on pelagial productivity, however, is thought likely to be small, given their slow rate of progression and their low concentrations of nutrients and organisms (low relative to those over the shelf, though high compared to the surrounding ocean; Shillington et al., 1990). Because upwelling intensity depends on the wind stress and the seasonally associated atmospheric changes, the offshore extension of upwelling and filaments also changes seasonally (Lutjeharms and Meeuwis, 1987).

Several studies carried out in the water column show that coccolithophorids, diatoms and foraminifera constitute the bulk of microplankton thriving in shelf waters off Namibia and South Africa. The occurrence of distinct species assemblages proved to be closely related with surface and subsurface waters masses of the region (e.g. Treppke et al., 1996; Giraudeau, 1993; Čepek, 1996; Giraudeau et al., 2000, and references therein). Calcareous and siliceous microfossils consti- tute some of the most common proxies used by marine paleoceanographers in order to unravel the past history of upwelling process and associated biogenic production of the BUS. For example, Giraudeau (1993) evaluated the foraminifera association, and described spatial variations in the intensity of coastal upwelling along the SW African coast. Müller et al. (1997) recorded the coccolithophorid species changes in late Quaternary sediments from the Walvis Ridge and
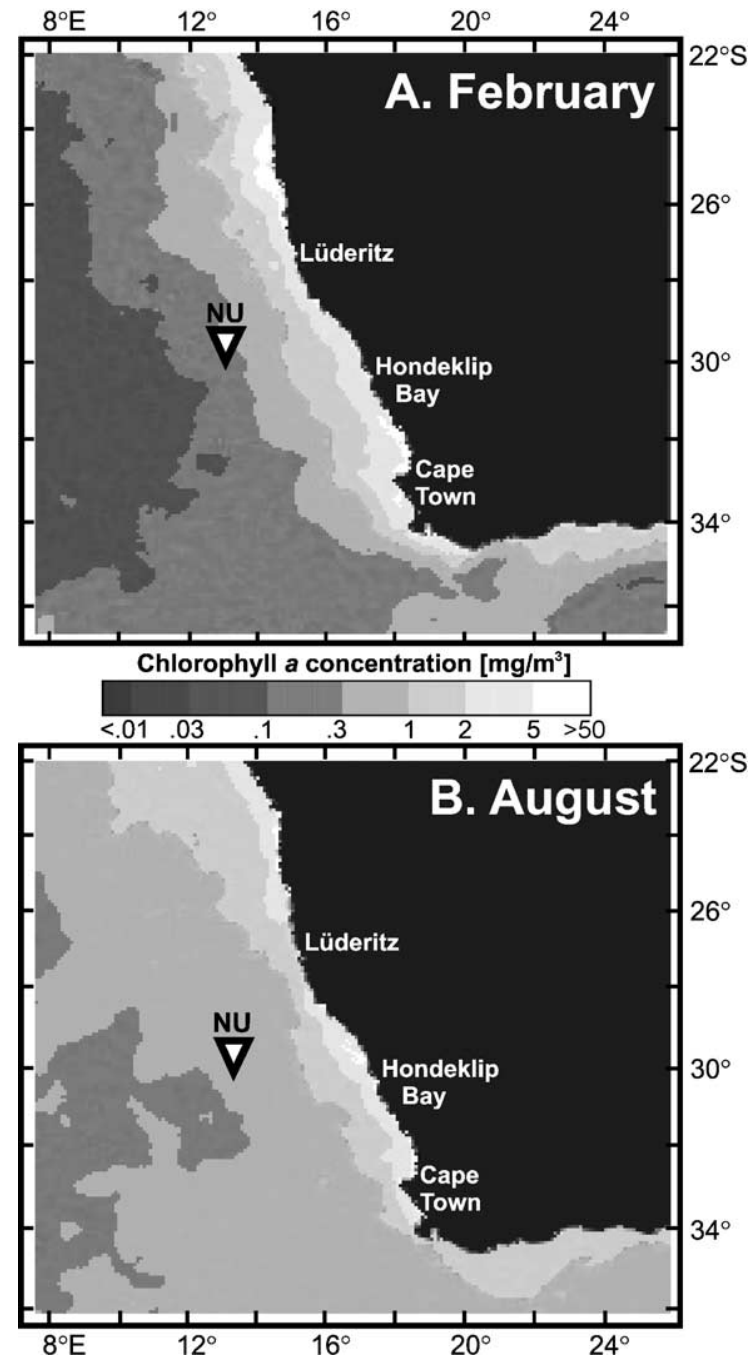

Fig. 1. Location of the NU mooring site (open triangle) in the central Benguela Upwelling System and long-term spatial distribution pattern of chlorophyll $a$ concentration in surface waters for February (A, upper part) and August (B, lower part). Pigment concentrations extracted from http://seawifs.gsfc.nasa.gov/SEAWIFS.html. 
discussed their implications for the alkenone paleotemperature record. More recently, Lange et al. (1999) characterized a distinct diatom maximum within the late Pliocene and early Quaternary, spanning the lower half of the Matuyama reversed polarity chron.

In this work, we examine 1 year of particle flux collected between January 1992 and January 1993 at the pelagic NU mooring site (Namibia Upwelling, ca. $29^{\circ} \mathrm{S}, 13^{\circ} \mathrm{E}$ ), located at the edge of the southernmost part of the central BUS with the Subtropical South Atlantic Gyre. We describe the intraannual dynamics of the bulk component, coccolithophorid, foraminifer and diatom fluxes and assemblages, as well as the $\delta^{15} \mathrm{~N}$ isotopic signal. A central objective was to determine whether and when offshore spreading of nutrient-rich filaments influences the primary and the secondary production of what is otherwise considered to be a meso-oligotrophic area (Berger, 1989).

\section{Oceanographic setting}

The central part of the BUS (ca. $25-31^{\circ} \mathrm{S}$ ) is almost permanently under the influence of upwelling-favourable winds (Shannon and Nelson, 1996). The presence of upwelled water is nearly constant over a large part of the continental shelf, with maxima in austral spring and summer and a minimum in fall (Shannon, 1985; Lutjeharms and Stockton, 1987). South of $31^{\circ} \mathrm{S}$, sea- sonality in the wind regime is stronger and upwellingfavourable winds also reach their maximum during austral spring and summer (Nelson and Hutchings, 1983; Shannon and Nelson, 1996). In addition, extensive seaward penetrations of upwelling plumes are seen off Lüderitz (ca. $27^{\circ} \mathrm{S}$ ) and Namaqua (or Hondeklip, ca. $30^{\circ} 30^{\prime} \mathrm{S}$ ). The latter upwelling cell, the closest to the NU trap site, preferentially grows westward, almost parallel to $30^{\circ} \mathrm{S}$ off SW Africa (Lutjeharms and Meeuwis, 1987). Satellite-derived images show that the seaward extent of filamentous components off the central BUS is increased in austral winter (August) in relation with austral summer (February; Fig. 1; see also Shannon, 1985; Lutjeharms and Stockton, 1987). Filament axes have a typical zonal dimension of 150-250 $\mathrm{km}$, but in extreme cases, they may stream up to 1000 km (Lutjeharms et al., 1991; Shannon and Nelson, 1996). This large field of chlorophyll filaments, much more extensive than that of the proper coastal upwelling, establishes a cold water archipelago, where a substantial or even major portion of the total primary production attributable to upwelling could directly take place (Lutjeharms and Stockton, 1987).

The water column at the NU site remains stable from November to April (mid-austral spring to early fall) (Fig. 2). Mixing starts in mid-austral fall and reaches its strongest phase in mid-austral winter. Sea surface temperatures (SST), measured at the mooring station and close to the coast at ca. $29^{\circ} \mathrm{S}$ in 1992 , depicts a

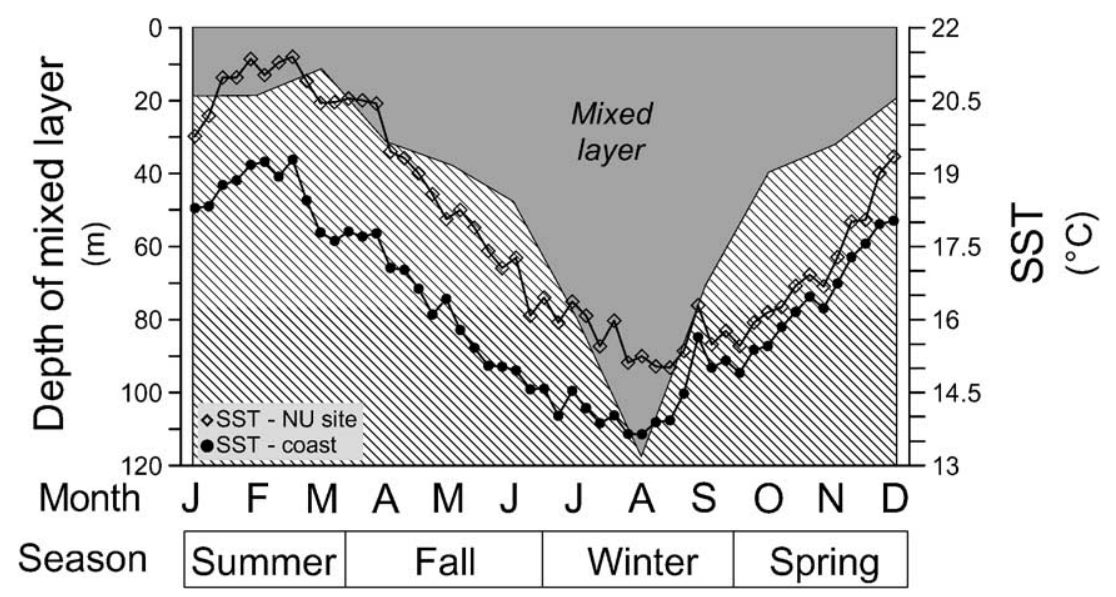

Fig. 2. Monthly average depth of the mixed layer (lighter grey shading) at the NU mooring site, and weekly sea surface temperatures (SST) close to the coast (closed circles) and at the NU mooring (open diamonds) during the period of trap deployment (January 1992-January 1993). SST blended from ship, buoy and bias-corrected satellite were extracted from http://ingrid.ldeo.columbia.edu/SOURCES/.IGOSS. The mixed layer depth were extracted from http://ingrid.ldeo.columbia.edu/SOURCES/. 
clear seasonal pattern, and closely follows the seasonal dynamics of the water column mixing. As shown in Fig. 2, SST were highest in austral summer and start to decrease when mixing of the water column began. Lowest SST values occurred in mid-austral winter, in coincidence with the mixing of the water column. Nearshore SSTs are $2{ }^{\circ} \mathrm{C}$ lower than at the mooring position from austral summer through late austral winter. With decreased mixing of the water column toward the end of the year, SST difference decreases.

The BUS is bounded by warm waters of the Angola Current in the north and of the western boundary Agulhas Current in the south. The southernmost penetration of Angolan waters over both Namibian shelf and slope occurs in austral summer and early autumn; maximum shedding of Agulhas waters onto the west coast of southern Africa tends to take place in austral summer and in early fall. In addition to being primarily fed by the South Atlantic Current, the Benguela Current can also be reached by the Agulhas Current and the Subantarctic Surface waters, the latter coming from perturbations in the Subtropical Front (Lutjeharms and Meeuwis, 1987; Peterson and Stramma, 1991).

\section{Material and methods}

A time-series sediment trap (SMT 230) was deployed at 2516-m water depth at the NU mooring site (Namibia Upwelling, $29^{\circ} 12^{\prime} \mathrm{S}, 13^{\circ} 07^{\prime} \mathrm{E}, 3055 \mathrm{~m}$ bottom depth) (Fig. 1) in the central BUS, off SW Africa, from January 1992 through January 1993. Sampling was at a 19-day interval. Samples were split into $1 / 16$ and 1/64 subsamples for analytical work. Before deployment, $1 \mathrm{ml}$ of saturated $\mathrm{HgCl}_{2}$ solution was added per $100 \mathrm{ml}$ of sample solution (seawater from 2000-m water depth) in order to retard microbial degradation of organic matter. $\mathrm{NaCl}$ was added to the sampling cups to reach a final salinity of $38-40 \%$. After recovery, samples were poisoned again with $\mathrm{HgCl}_{2}(0.5 \mathrm{ml} / 100 \mathrm{ml}$ of seawater $)$ and stored at $4{ }^{\circ} \mathrm{C}$.

The splitting procedure and chemical analyses of the $<1-\mathrm{mm}$ fraction were carried out at Bremen University according to the methods described by Fischer and Wefer (1991). We performed organic carbon and carbonate analysis on freeze-dried material using a Heraeus-CHN analyzer. Organic carbon was calculated as $\mathrm{C}_{\text {org }}=\mathrm{C}_{\text {total }}-\mathrm{C}_{\mathrm{CaCO}_{3}}$. The contribution of lithogenic material was calculated as lithogenic $=$ total - biogenic opal - carbonate - organic matter $\left(\sim 2 \times \mathrm{C}_{\text {org }}\right)$. Biogenic opal was determined using a sequential leaching technique (DeMaster, 1981), modified by Müller and Schneider (1993).

For diatom analysis, original samples were rinsed with distilled water and prepared according to the methodology proposed by Simonsen (1974). Qualitative and quantitative analyses were done at $\times 400$ and $\times 1000$ magnifications using a Zeiss Axioscope with phase-contrast illumination. Counts were carried out on permanent slides (Mountex mounting medium) of acidcleaned material. Several traverses across the coverslip were examined depending on microorganism abundances. As a whole, between 450 and 1000 valves were counted for each slide. At least two slides per sample were scanned in this fashion. The conventions proposed by Schrader and Gersonde (1978) for counting of valves and fragments were adopted. For diatoms, each individual was identified to the lowest possible taxonomic level. Counting of replicate slides indicated that the analytical error of the flux estimates is $\leq 15 \%$. The resulting counts yielded estimates of daily fluxes of diatom valves per square meter per day calculated according to Sancetta and Calvert (1988), as well as relative abundance of species or group of species.

For coccolithophore analysis, aliquots of $1 / 250$ were used. They were further wet-split using an electrical rotary sample divider (Fritsch, Laborette 27) with tap water as splitting medium. Due to varying particle content and turbidity of the samples, different aliquots were used, ranging from $1 / 400$ to $1 / 12800$. In order to disintegrate aggregates, the samples were placed in an ultrasonic bath only for $30 \mathrm{~s}$ (Andruleit, 1996). The aliquots were then filtered onto polycarbonate membranes (Schleicher and Schuell ${ }^{\mathrm{TM}} 47-\mathrm{mm}$ diameter, $0.4-\mu \mathrm{m}$ pore size) and carefully rinsed with tap water to avoid the growth of salt crystals while drying. After storage in an oven at $45{ }^{\circ} \mathrm{C}$ for $24 \mathrm{~h}$, a small piece of the filter (ca. $0.25 \mathrm{~cm}^{2}$ ) was cut and mounted on an aluminum stub. For qualitative and quantitative analysis, the samples were examined with a scanning electron microscope $(\mathrm{SEM})$ at a $5000 \times$ magnification. In each sample, at least 500 coccoliths were counted on a randomly selected transect with a scanning area of $0.03-0.5 \mathrm{~mm}^{2}$. The conversion of coccolith/coccosphere countings into daily coccolith/ 
coccosphere fluxes followed the formula given by Andruleit (1996):

Coccolith flux (no. of coccoliths $\mathrm{m}^{-2}$ day $^{-1}$ )

$$
=\frac{F \times C \times S}{A \times D \times O}
$$

where $F=$ effective filtration area $\left(\mathrm{mm}^{2}\right) ; C=$ number of coccoliths counted; $S=$ split factor; $A=$ investigated filter area $\left(\mathrm{mm}^{2}\right) ; D=$ sampling interval (days); and $O=$ area of the trap aperture $\left(\mathrm{m}^{2}\right)$. Daily coccosphere fluxes were calculated using the same equation, with $C$ as number of coccospheres counted.

Foraminifers were rinsed several times with fresh water and dried at $50{ }^{\circ} \mathrm{C}$, then separated and weighed. Analysis of the foraminiferal species assemblage was done for individuals $>150 \mu \mathrm{m}$. Shells collected in the traps were primarily empty, that is, dead individuals on their way to the sea floor. In total, 12 planktonic species were found in the samples.

$\delta^{15} \mathrm{~N}$ measurements were performed on a Finnigan Delta Plus attached to a Carlo/Erba NC2500 automatic elemental analyser as preparation line. The stable isotope determination was made from $\mathrm{N}_{2}$ gas released by flash combustion in excess oxygen at $1050{ }^{\circ} \mathrm{C}$. Depending on the organic content, between 3 and 10 $\mathrm{mg}$ of bulk material (freeze-dried and homogenised) was taken in and measured against $99.996 \%$ pure $\mathrm{N}_{2}$ tank gas. One internal standard (WST2 6.66\%o) was measured for every fifth sample. The $\mathrm{N}_{2}$ tank gas and the WST2 internal standard were calibrated against the IAEA standards N-1 and N-2. Standard deviation, determined from replicate measurements, was $<0.2 \%$.

The principal components analysis (PCA) has been performed using STATISTICA 5.5 (StatSoft, 2001). The extraction of principal components amounts to a variance maximizing (varimax) rotation of the original variable space. The criterion for the rotation is to maximize the variance (variability) of the "new" variable (factor), while minimizing the variance around the new variable. For the PCA, we used the coccolith, foraminifera and diatom species or groups of species plotted in Figs. 4-6. The organism dataset from sediment traps results in four factors (assemblages) which account for ca. $89 \%$ of the original variance (Table A3). Fifteen counting groups in 20 samples resolved these four factors. Each counting group exceeded $1.5 \%$ in at least one sample.

\section{Results}

4.1. Intraannual variations in bulk composition and $\delta^{15} \mathrm{~N}$ isotopic signal

\subsubsection{Bulk composition}

The general seasonal trend of the total flux of particulates at the NU mooring site shows a bimodal distribution with high values in mid-austral summer and mid-austral winter, and moderate to very low values in spring and fall (Fig. 3a) (Table A1). The total flux ranged from a maximum of ca. $200 \mathrm{mg} \mathrm{m}^{-2}$ day $^{-1}$ to a minimum of $12 \mathrm{mg} \mathrm{m}^{-2}$ day $^{-1}$. Calcium carbonate was the dominant bulk component (daily average $=58.4 \mathrm{mg} \mathrm{m}^{-2} \mathrm{day}^{-1}$ ) (Fig. 3b). Its relative contribution exceeded $60 \%$ of the total particle flux at any time (daily average $=69.4 \%$ ). The highest relative concentration of calcium carbonate is seen at the NU site from mid-austral fall through mid-austral winter.

Lithogenic particles, biogenic opal and organic carbon were secondary contributors to the particle flux (Fig. 3c-e). The percentage of lithogenic particles varied strongly (range $=\sim 7.3-19.9 \%$, daily average $=14.3 \%$ ). The flux of biogenic opal was at its highest in austral winter, with secondary peaks in summer and spring, while the highest relative contribution is seen between late austral winter and late spring. Organic carbon flux was highest in austral summer, with secondary peaks in austral winter and spring. Its relative contribution varied less (range $=$ $\sim 4.0-7.5$, daily average $=5.0 \%$ ).

\subsection{2. $\delta^{15} N$ isotopic signal}

Values were highest in austral summer (maximum $=8.3 \%$ ), but remained rather high through fall (Fig. 3f) (Table A1). Lowest values (4.25-4.35\%o) were recorded in winter, in accordance with high fluxes of total mass, calcium carbonate and organic carbon and the highest opal value.

\subsection{Composition of the calcium carbonate fraction}

\subsubsection{Coccolithophorids}

The calcium carbonate fraction was mainly composed of coccolithophorids, foraminifera and pteropods. Comparison of the two coccolithophorid fractions (free coccoliths and coccospheres) showed quantitative differences. The number of coccospheres was two 

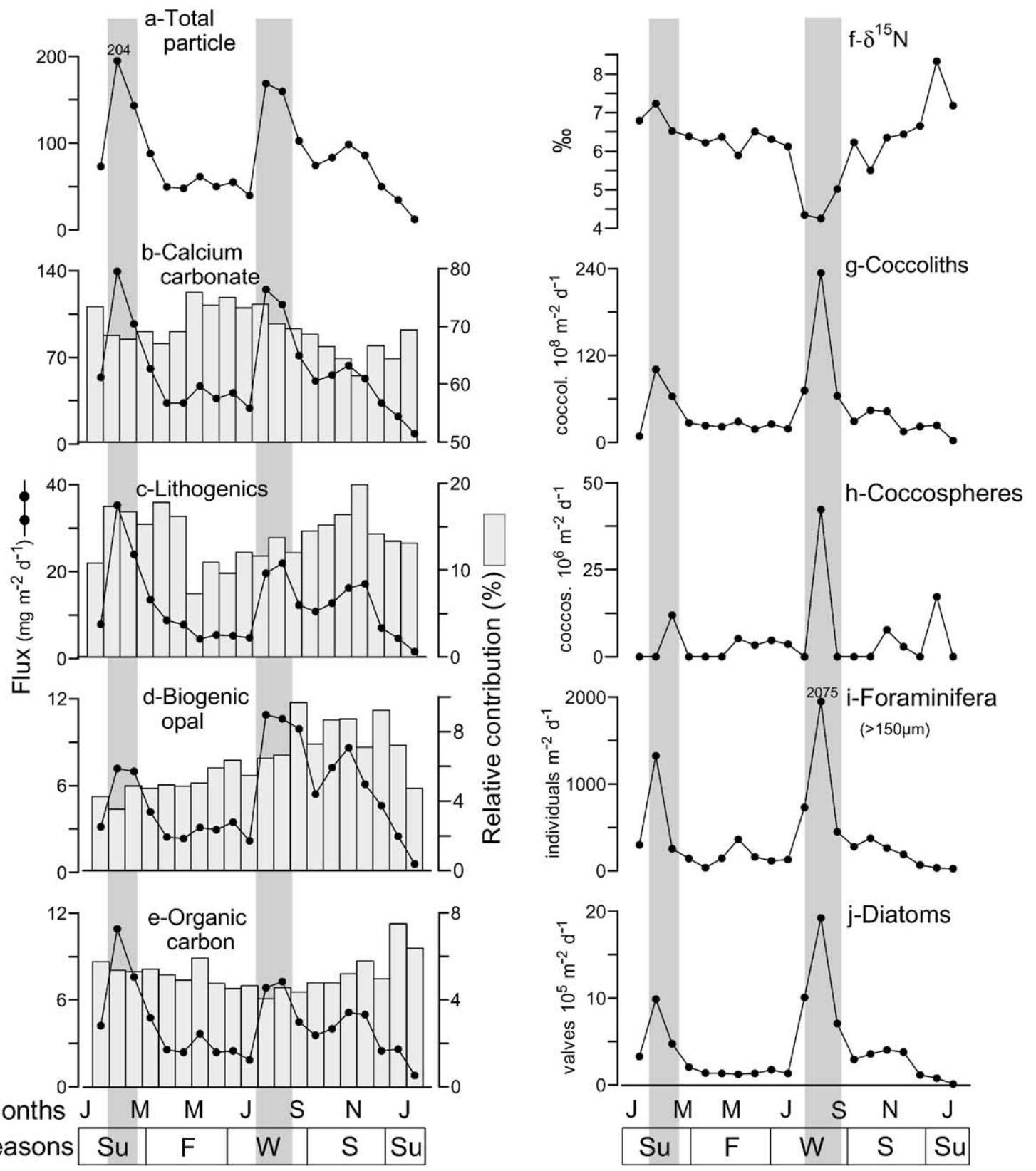

Fig. 3. Seasonal pattern of flux of (a) total particle, (b) calcium carbonate, (c) lithogenics, (d) biogenic opal, (e) organic carbon, (f) $\delta^{15} \mathrm{~N}$, (g) coccoliths, (h) coccospheres, (i) foraminifera and (j) diatoms at the NU mooring site in the central Benguela Upwelling System between January 1992 and January 1993. In addition, the relative contribution of calcium carbonate, lithogenics, biogenic opal and organic carbon is shown in gray bars. Grey shadings highlight periods of higher fluxes. See also Table A1.

orders of magnitude lower than that of the free coccolith flux $\left(10^{6}\right.$ vs. $10^{8}$; Fig. $3 \mathrm{~g}$ and h; Table A1). Both coccolith and coccosphere fluxes exhibited the most pronounced peak in winter. A secondary max- imum occurred mid-summer. Additionally, the coccospheres peaked again at the end of the sampling period (spring-summer transition). In both fractions, very low values occurred during fall and spring. No 
significant correlation exists between coccosphere flux and those of total mass and calcium carbonate $(r=0.33$ and 0.28 , respectively).

The free coccolith community was clearly dominated by Emiliana huxleyi (Lohmann) Hay and Moler (range relative abundance $=41-79 \%$, annual average $=$ 64.5\%) (Fig. 4a). Secondary contributors were Calcidiscus leptoporus (Murray and Blackman) Loeblich and Tappan (4.0-11.5\%), Florisphaera profunda Oka-

\section{Coccoliths}
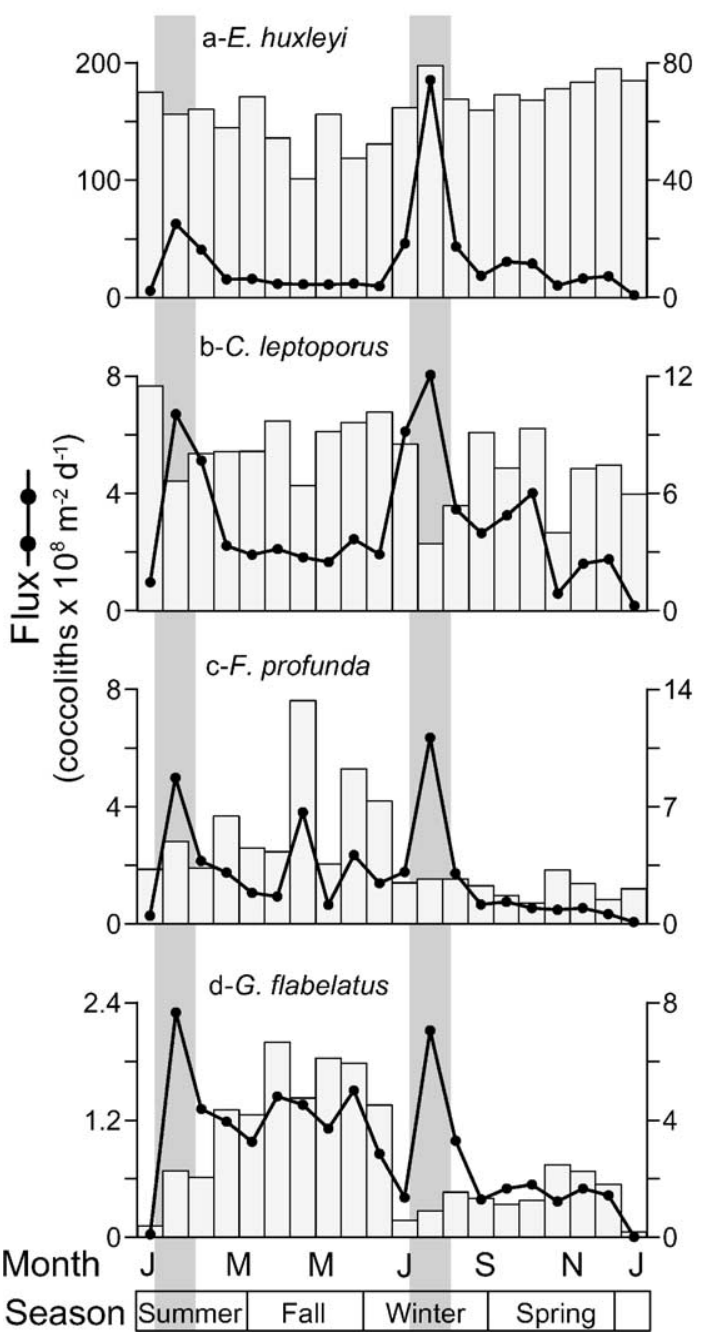

da and Honjo (ca. 1.5-13\%) and Gladiolithus flabellatus (Hadall and Markali) Jordan and Chamberlian (ca. $0.2-6.5 \%$ ) (Fig. 4b-d). Both coccolith maxima were dominated by $E$. huxleyi. Most elevated relative abundance of F. profunda and G. flabellatus, species thriving in the low photic zone (LPZ), were recorded in austral fall.

With only four different taxa, diversity of the coccosphere assemblage was much lower than that of the free

\section{Coccospheres}

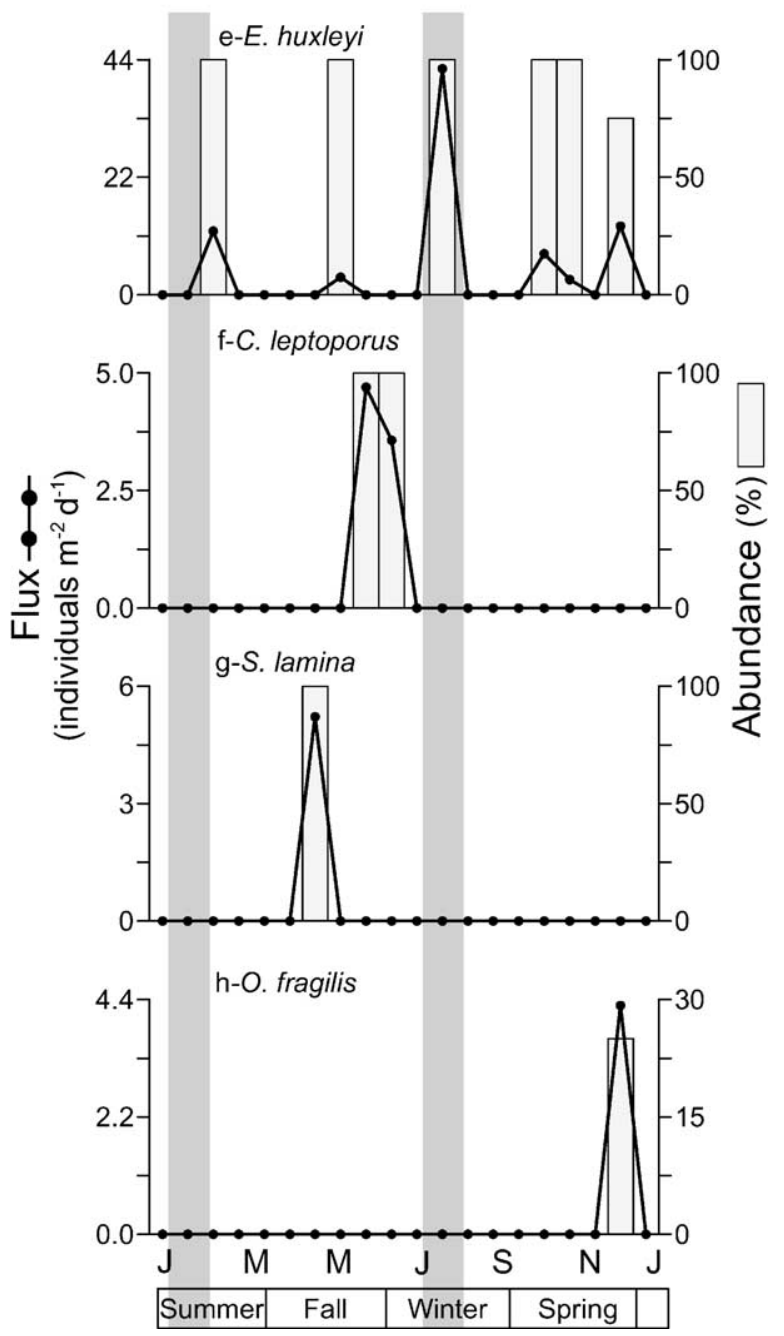

Fig. 4. Seasonal pattern of flux (solid line) and relative abundance (bars) of the most abundant species of coccoliths (left-hand side) and coccospheres (right-hand side) at the NU mooring in the central Benguela Upwelling System between January 1992 and January 1993. Grey shadings highlight periods of higher fluxes. 
coccolith assemblage, composed of 61 different species (Table A2). The coccosphere assemblage was also dominated by E. huxleyi, with subordinate contributions by C. leptoporus, Syracosphaera lamina LecalSchlauder and Oolithus fragilis (Lohmann) Martini and Müller (Fig. 4e-h).

\subsubsection{Planktonic foraminifera $(>150 \mu \mathrm{m})$}

Planktonic foraminifera were present throughout the sampling period (Fig. 3i) (Table A1). The two main peaks in mid-austral summer and mid-winter followed the general pattern of total mass and calcium carbonate. A noteworthy difference was observed: while calcium carbonate maximum was highest in austral summer, foraminifera had their highest flux in austral winter. High contribution of carbonate-skeleton bearing pteropods in mid-austral summer (Donner, unpublished data) might explain the weakened correlation between foraminifera and calcium carbonate fluxes in summer.

The planktonic Globorotolia inflata (d'Orbigny) clearly dominated the foraminiferal assemblage from January 1992 through January 1993: its relative contribution ranged $22-86 \%$, and the mean annual relative abundance raised up to ca. 54\% (Fig. 5a). The highest peak of the $G$. inflata flux occurred in midaustral winter; a secondary maximum was seen in mid-summer. Subordinate contributions to the foraminiferal assemblage were made by the dextral $\mathrm{NeO}$ globoquadrina pachyderma (Ehrenberg), Globigerina bulloides (d'Orbigny), Orbulina universa (d'Orbigny) and Globigerinoides ruber white (d'Orbigny). The right-coiled N. pachyderma mostly followed the seasonal pattern of the total particle, calcium carbonate and foraminiferal fluxes, with an additional peak in early austral spring (Fig. 5b). G. bulloides mainly contributed in mid-austral winter and early spring, with a secondary maximum in austral summer, while $O$. universa had a less-defined seasonal pattern with maxima almost in each season (Fig. 5c and d). Main flux contribution of $G$. ruber white was observed in later summer and early fall, when flux of particulates was rather low (Figs. 3 and 5e).

\subsection{Composition of the biogenic opal fraction}

The biogenic opal flux was composed by diatoms, silicoflagellates, radiolarians, phytoliths and the dinoflagellate Actiniscus pentasterias (Ehrenberg) Ehren-

\section{Foraminifera} $(>150 \mu \mathrm{m})$
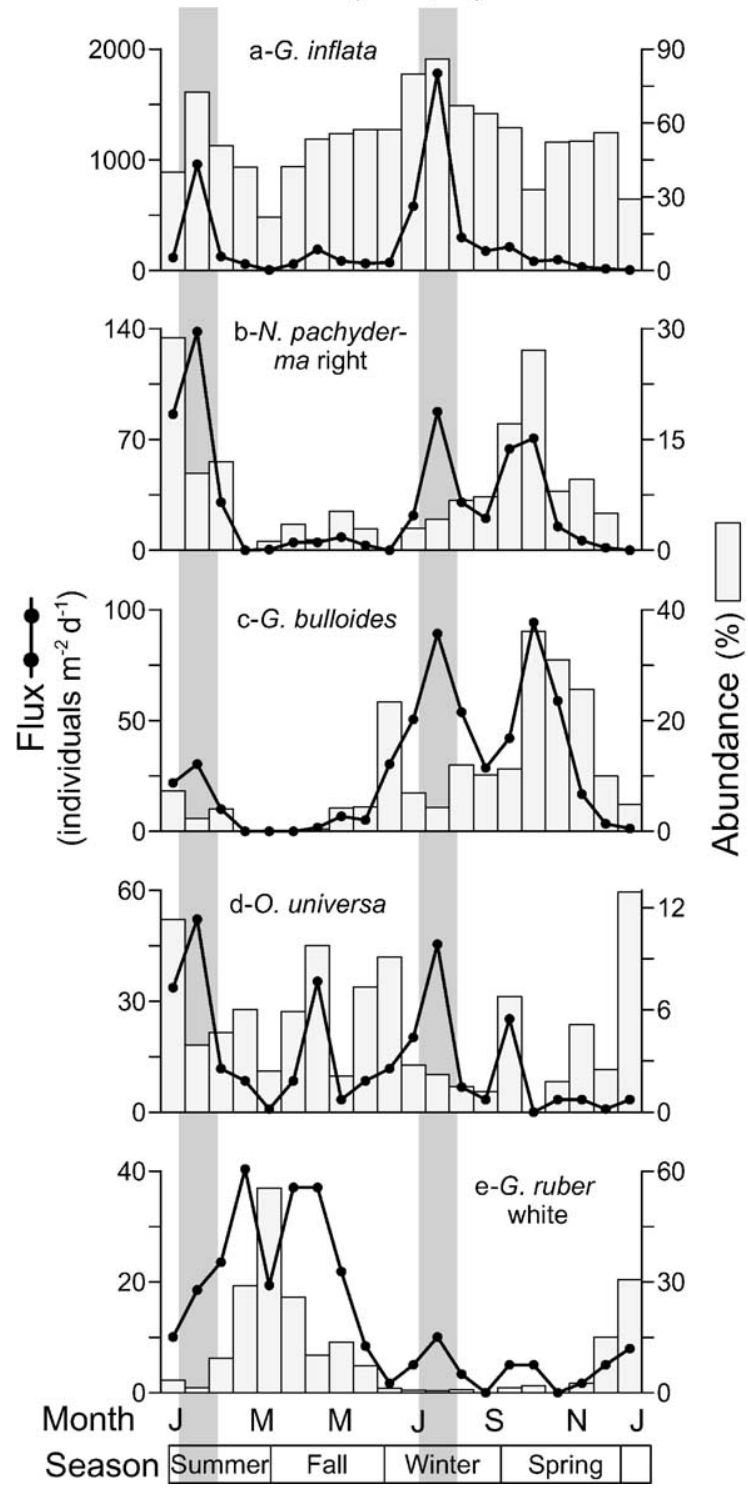

Fig. 5. Seasonal pattern of flux (solid line) and relative abundance (bars) of the most abundant species of foraminifera at the NU mooring site in the central Benguela Upwelling System between January 1992 and January 1993. Grey shadings highlight periods of higher fluxes.

berg. As number of individuals, diatoms dominated the biogenic opal fraction throughout the year: their flux was always one to four orders of magnitude higher than that of above-mentioned siliceous organisms. Following the seasonal course of the coccolithophor- 
ids and foraminifera, diatoms also occurred in greatest numbers in mid-austral winter, and secondarily in austral summer (Fig. 3i) (Table A1).

The highly diverse diatom assemblage was composed by almost 98 species and varieties (Table A2). Regardless of the season, less than 12 species or group of species accounted for $75 \%$ of the total diatom flux. Most important contributors to the diatom flux were the pelagic species Fragilariopsis doliolus (Wallich) Medlin and Sims, Azpeitia tabularis (Grunow) G. Fryxell and T.P. Watkins, A. neocrenulata (Van Landingham) G. Fryxell and T.P. Watkins, and Thalassionema nitzschioides var. inflata Kolbe, accompanied the neritic Actinocyclus curvatulus Janisch, A. octonarius Ehrenberg and Coscinodiscus radiatus Ehrenberg (Fig. 6a-f). F. doliolus dominated the diatom assemblage throughout the sampling period (range relative contribution $=11-68 \%$, annual average $=$ $34 \%$ ). On a yearly basis, the average relative abundance of neritic $A$. curvatulus, $A$. octonarius and $C$. radiatus reached all together approximately $20 \%$. Subordinate contributions to the neritic diatom assemblage were made by resting spores (RS) of Chaetoceros spp. and Thalassiosira oestrupii var. venrickae G. Fryxell and Hasle. T. frauenfeldii (Grunow) Hallegraef, T. nitzschioides var. parva (Heiden) MorenoRuiz and T. ferelineata Hasle and G. Fryxell occasionally contributed to the oceanic diatom association.

The diatom community was highly diversified during the austral summer diatom peak. Oceanic and neritic diatoms equally contributed to this maximum, with $A$. curvatulus as the dominant species, closely

\section{Pelagic diatoms}

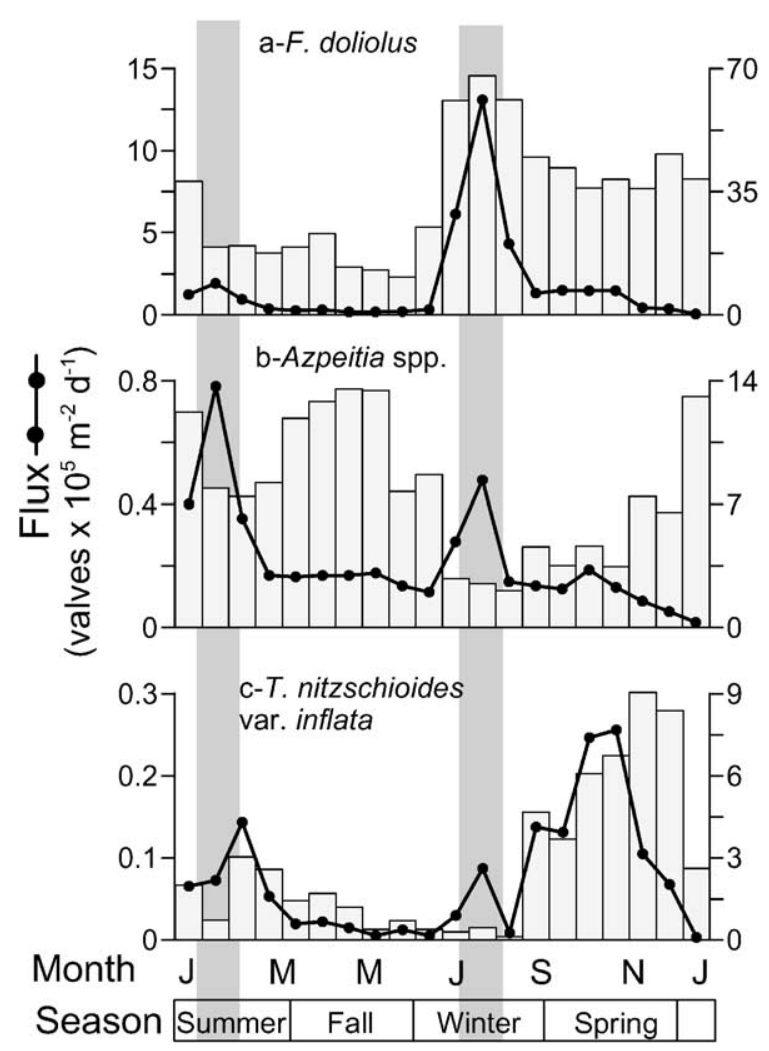

\section{Neritic diatoms}

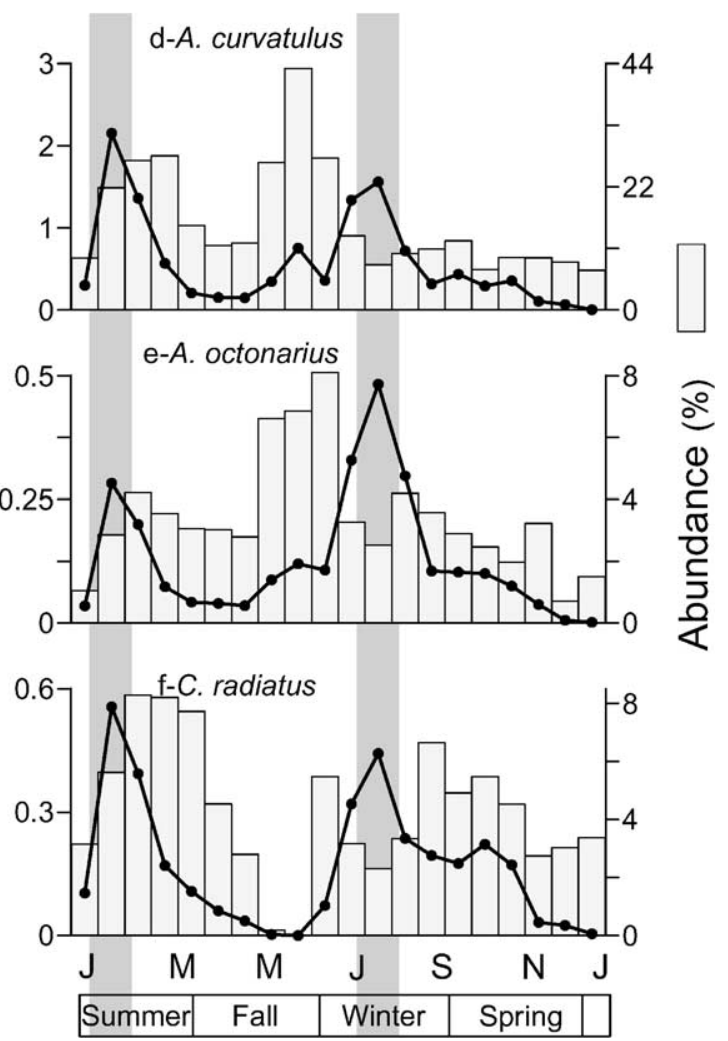

Fig. 6. Seasonal pattern of flux (solid line) and relative abundance (bars) of the most abundant pelagic (left-hand side) and neritic diatom species (right-hand side) at the NU mooring site in the central Benguela Upwelling System between January 1992 and January 1993 . Grey shadings highlight periods of higher fluxes. 
followed by $F$. doliolus. Minor contributions correspond to neritic RS Chaetoceros and T. oestrupii var. venrickae, and open-ocean species of Azpeitia. This situation is clearly reflected by the Shannon-Weaver diversity index, which raised up to 2.98 in mid-austral summer 1992. With a diversity index of 1.53 , the main diatom peak in austral winter was substantially less diversified than the summer one: $F$. doliolus relative contribution raised up to $68 \%$, while neritic diatom species hardly reached $20 \%$. Highest relative contribution of neritic diatoms was observed in late fall, with A. curvatulus as the main component (ca. $43 \%$ ).

\section{Discussion}

\subsection{Intraannual variations of bulk components and the $\delta^{15} N$ isotopic signal}

The recorded pattern of flux of bulk components and organisms at the pelagic NU site off SW Africa at $29^{\circ} \mathrm{S}$ is well correlated with the annual cycle of the dominant oceanographic features for the southernmost part of the central BUS. The mooring location is mostly under the influence of open-ocean waters, but the seasonal intensification of coastal upwelling and the seaward extension of chlorophyll filaments is also reflected by the trapped particulate material, as well as in both calcareous and siliceous plankton fractions.

The maximum export of particulates in austral summer at the NU site is probably due to the more intense offshore spreading of nutrient-rich waters of the Namaqua upwelling cell from July through September (Nelson and Hutchings, 1983; Shannon and Nelson, 1996). The occurrence of the planktonic foraminifera $N$. pachyderma dextral, together with the highest flux of neritic diatoms, also reflects influence of near-shore waters. Maximum export of particulates in austral winter seems to be predominantly the consequence of in situ production, favoured by strong mixing and low SST at the edge of the Subtropical South Atlantic Gyre (Fig. 2). As stated by Shannon (1985), a winter cooling of surface waters, due to low insolation and stormy weather, might be even more efficient than cooling caused by coastal upwelling. Additional input from the coastal and shelf upwelling areas derived from chlorophyll filaments, persistently developed in austral winter (Lutjeharms and Meeuwis, 1987). Though these filaments usually extend seaward between 150 and 250 $\mathrm{km}$, extreme events they may stream up to $1000 \mathrm{~km}$ (Lutjeharms et al., 1991; Shannon and Nelson, 1996). The $\delta^{15} \mathrm{~N}$ isotopic signal at the NU site only partially covaries with the seasonal variability of the particle flux. The $\delta^{15} \mathrm{~N}$ signal shows low variations during austral summer and fall, without reflecting the summer particle flux maximum. This lack of correlation might have been caused by a different nutrient source with a heavier $\mathrm{N}$-isotopic signal composition. A certain influence from the coastal area of intermediate water is suggested by the lowest $\delta^{15} \mathrm{~N}$ values, which caused a lighter $\mathrm{N}$-isotope signal due to lower relative nitrate utilization rates (Altabet et al., 1991). The $\delta^{15} \mathrm{~N}$ isotopic signal generally shows variation along with the SST recorded at the SW African coast. An almost similar pattern in terms of seasonality and absolute values of $\delta^{15} \mathrm{~N}$ has been recorded farther north at the Walvis Ridge by Holmes et al. (2002).

\subsection{Seasonal pattern of the carbonate and siliceous plankton assemblages}

The temporal variations in composition of the coccolithophorid, adult foraminifer and diatom populations also mirror the seasonal changes of main hydrographic conditions close to the NU site off SW Africa. In coincidence with previous observations in the northern and central area of the BUS (Giraudeau and Bailey, 1995; Čepek, 1996; Baumann et al., 1999), the cosmopolitan coccolithophorid E. huxleyi dominated both coccolith and coccosphere assemblages from January 1992 through January 1993. It has been reported that E. huxleyi quickly responds to nutrient enrichment by increasing their population size at a wide spectrum of environments, such as edges of subtropical gyres, in equatorial and coastal upwelling areas and on continental shelves (Giraudeau and Bailey, 1995). Subordinate contribution by C. leptoporus, whose timing parallels to that of calcium carbonate and total mass, is related with waters of moderate productivity waters (Giraudeau, 1992; Giraudeau and Bailey, 1995), and defines the transition from coastal, colder to warmer, pelagic waters of the eastern boundary of the Subtropical South Atlantic Gyre. The increased relative contribution of the LPZ species F. profunda and $G$. flabellatus (Okada and Honjo, 1973; Winter et al., 1994) from late austral summer to early winter agrees with a well-stratified water column and the prevailing 
oligotrophic conditions at the NU mooring site. When stratification breaks down in early austral winter (Fig. 2 ), and coastal waters intrude, relative abundance of the LPZ taxa abruptly dropped while the percentage of $E$. huxleyi increased (Fig. 4).

The succession in the community of adult planktonic foraminifera is coupled with the dynamics of the main hydrographic setting. Predominance of the deepliving planktonic foraminifera $G$. inflata reflects the oligotrophic conditions of the Subtropical South Atlantic Gyre (Oberhänsli et al., 1992; Kemle-von Mücke and Oberhänsli, 1999), and reduced upwelling conditions (Giraudeau, 1993; Giraudeau and Rogers, 1994). Giraudeau et al. (2000) consider the right-coiled $N$. pachyderma as upwelling indicator for the BUS. Our observations coincide with those by Giraudeau et al.: in NU samples, the highest flux of dextral N. pachyderma occurred in austral summer, with lessened values in winter and spring, and lowest ones in fall, hence, paralleling well the seasonal dynamics of coastal upwelling in the central part of the BUS (Lutjeharms and Meeuwis, 1987; Shannon and Nelson, 1996). The planktonic foraminifera G. bulloides might have reached the NU mooring site along with nutrients by deep-vertical mixing from below the nutricline, as well as benefited from the high primary productivity of surface waters derived from offshore transport of coastal waters in austral winter and spring (Kemlevon Mücke and Oberhänsli, 1999).

Qualitative variations in the diatom assemblage also reflect the different water sources reaching the NU mooring site. Neritic diatoms A. curvatulus and $C$. radiatus reached their highest flux in austral summer, in coincidence with the strong seasonal seaward migration from the coastal waters (Lutjeharms and Meeuwis, 1987; Shannon and Nelson, 1996). The diatom assemblage can be characterized as "mixed" during the summer peak and the low diatom export in late austral fall-early winter, when coastal and oceanic species equally contribute to the diatom community. This suggests a relatively constant input from the coastal area into the open ocean realm that continues throughout the season of lessened coastal upwelling (Lutjeharms et al., 1991). The strong dominance of the mesotrophic, tropical-subtropical water associated $F$. doliolus in the austral winter diatom peak points to the predominance of in situ production, probably favoured by a strongly mixed water column. Still, some influ- ence from the coastal area is seen, as suggested by the minor occurrence of neritic diatoms in winter. Dominance of pelagic diatom species after the austral winter peak till late spring 1992 evidences that the oligotrophic Subtropical South Atlantic Gyre remains the main source of water masses at the NU site with reduced influence from coastal areas.

The simultaneous occurrence of calcareous and siliceous plankton with different ecological requirements reflects the fact that the NU trap was deployed in a transitional area between offshore and the coastal waters, where considerable hydrographic variability over short-time intervals exists. Table 1 summarizes the main features of the intraannual distribution of the flux of bulk components and organisms at the NU site. We propose that the influence of the coastal upwelling Namaqua cell, reaching the trap site through chlorophyll filaments, is strongest in austral summer. During the austral winter export peak, though some seaward transport via chlorophyll filaments is still observed, the pelagic NU site is less influenced by coastal waters, being particles and organisms partially produced close to the mooring site.

The above-presented summary is supported by the principal components analysis of the microorganism populations (Fig. 7) (Table A3). Factor 1, which explains $\sim 55 \%$ of the variance, is dominated by the coccolithophorids $F$. profunda, G. flabellatus (both typical for the LPZ) and C. leptoporus, and the diatoms Azpeitia spp., A. curvatulus and C. radiatus. Except for F. profunda and C. leptoporus, all these organisms had their highest fluxes during the austral summer, though the relative contributions show rather different seasonal patterns. The only planktonic foraminifera with a high contribution in this factor is G. inflata. Factor 3 ( $\sim 10.6 \%$ of the total variance) can be characterized as the "winter factor." Main components are the coccolithophorid E. huxleyi, the planktonic foraminifera $G$. inflata and $G$. bulloides and the diatoms $F$. doliolus and A. octonarius. The flux of almost each Factor 3 components peaked in austral winter. Factor 2 accounts for $15.5 \%$ of the variance and is dominated by the planktonic foraminifera $N$. pachyderma right, $O$. universa and G. ruber white. This factor represents a seasonally "mixed" signal (see Fig. 5). The pelagic diatom T. nitzschioides var. inflata, the main component of Factor 4, represent the spring signal. The planktonic foraminifer $N$. pachyderma right and the 
Table 1

Summary of the main characteristics of the intrannual particle flux at the NU mooring site $\left(29^{\circ} 12^{\prime} \mathrm{S}, 13^{\circ} 07^{\prime} \mathrm{E}\right)$ in the central Benguela Upwelling System (January 1992-January 1993)

\begin{tabular}{ll}
\hline Summer maximum & Winter maximum \\
\hline Total mass flux & \\
$204 \mathrm{mg} \mathrm{m}^{-2}$ day $^{-1}$ & $160-169 \mathrm{mg} \mathrm{m}^{-2}$ day $^{-1}$
\end{tabular}

\section{Bulk components (\%)}

Calcium carbonate: 68

Biogenic opal: 3.5

Organic carbon: 5.4

Lithogenics: 17.3

Calcium carbonate: $70.5-74$

Biogenic opal: $6.5-6.7$

Organic carbon: $4.0-4.6$

Lithogenics: $11.6-13.7$

Isotopic signal $\left(\delta^{15} N\right)$

High $(7.2 \% 0)$

Low $(4.25 \% 0)$

Floral and fauna composition (PCA)

Coccolithophorids
F. profunda, G. flabellatus, C. leptoporus

Diatoms

Azpetia spp., A. curvatulus,

C. radiatus
E. huxleyi
F. doliolus, A. octonarius

Foraminifera

G. inflata, G. bulloides

Main factors and/or processes influencing the dynamics of particle flux

*Increased influence of coastal upwelling

Namaqua cell

*Minor seasonal offshore spreading of chlorophyll filaments

*Less in situ production

* Low mixing of the water column

*Reduced influence of coastal upwelling

* Major seasonal offshore spreading of chlorophyll filaments

*High in situ production

*Strong mixing of the water column via storms

Values and organism assemblages given correspond to the main seasonal peaks (austral summer and winter; see Figs. 3-6). The floral and fauna associations typical for austral summer and winter derive from the principal components analysis (see Fig. 7 and Table A3).

diatoms Azpeitia spp. and C. radiatus also share high values in Factor 4.

\subsection{Regional variability of particle fluxes off South- western Africa}

We now compare the northern WR and NU mooring sites. The WR mooring was deployed in the Walvis Ridge (northern BUS, ca. $20^{\circ} \mathrm{S}, 9^{\circ} \mathrm{E}$; ca. $600-\mathrm{m}$ water depth), in a transition area between coastal and open-

ocean regimes, between March 1989 and February 1992. Although fluxes at both trap sites were obtained during different sampling periods and traps were deployed at different depths, a general pattern in the mean annual values and the seasonal dynamics is recognized. The magnitude and seasonal variations of the flux of bulk components, and the qualitative changes in the microorganism populations allow us to characterize and distinguish the northern and central pelagic areas of the BUS.

In good agreement with primary productivity values calculated from satellite imagery (Antoine et al., 1996), the yearly flux of total mass recorded at the WR site is higher than that collected at the NU site (Table 2). At both sites, sedimentation of particulates is clearly biogenic, dominated by calcium carbonate, mainly delivered by coccolithophorids and foraminifera. Organic matter and biogenic opal (mainly diatoms) are secondary components, while the input of terrigenous material remains moderate to low at both sites (less than 15\%). Striking differences among the bulk components at both trap locations lay in the higher absolute con-

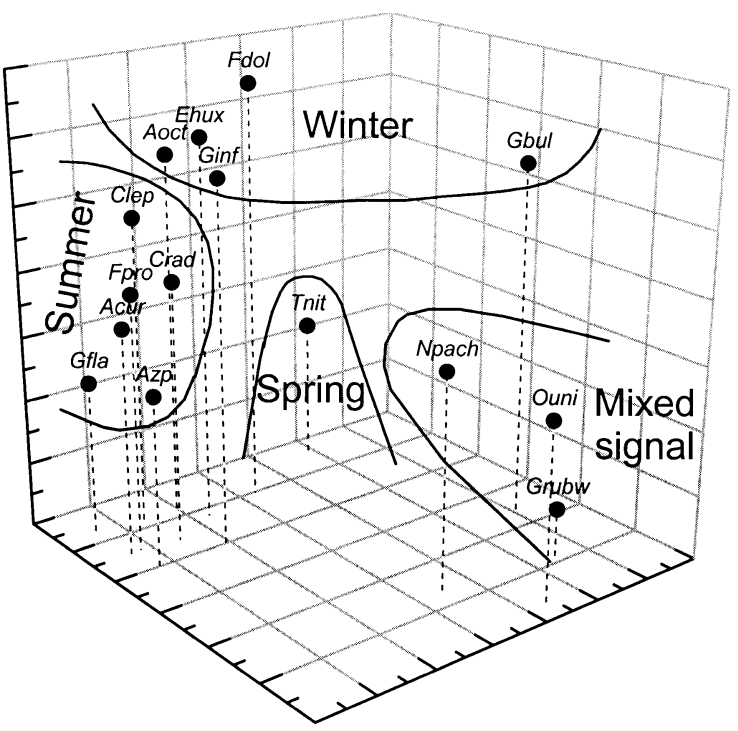

Fig. 7. Three-dimensional scatter plot of Factors 1, 2 and 3 based on principal components analysis (rotation, varimax normalized). The three factors account for $81.25 \%$ of the total variance (see also Table A3). Acur: A. curvatulus; Aoct: A. octonarius; Azp: Azpeitia spp.; Clep: C. leptoporus; Crad: C. radiatus; Ehux: E. huxleyi; Fpro: F. profunda; Fdol: F. doliolus; Gfla: G. flabellatus; Gbul: G. bulloides; Grubw: G. ruber white; Ginf: G. inflata; Npach: N. pachyderma; Ouni: O. universa; Tnit: T. nitzschioides var. inflata. 
tribution of organic carbon (almost threefolds higher), and the higher flux of calcium carbonate at the WR site. Among the calcium carbonate producers, coccoliths (as number per day) contributed the most at the NU site, while the opposite is true for foraminifera: highest yearly flux was recorded at the WR site. Though interannual variability is expected and differences in trap depth should be kept in mind, the diatom flux at the WR site in 1989 was one order of magnitude higher than at the NU site.

As for other trap sites close to or under the influence of coastal upwelling, main bulk components at WR and NU sites yield high seasonality, mostly showing a typical bimodal pattern. Bulk components, siliceous phytoplankton and coccolith maxima in austral spring and fall in the Walvis Ridge are directly correlated with the seasonal dynamics of coastal upwelling occur- rence, offshore migration of chlorophyll filaments off Cape Frio $\left(19^{\circ} \mathrm{S}\right)$, and the bimodal pattern of wind stress (Shannon and Nelson, 1996). In turn, fluxes are inversely correlated with SST fluctuations (Wefer and Fischer, 1993; Fischer and Wefer, 1996; Čepek, 1996; Treppke et al., 1996; Romero et al., 1999). According to Lutjeharms and Stockton (1987), it is particularly noticeable that the Cape Frio upwelling plume seems to follow the bottom topography of the Walvis Ridge, reaching the WR site as an effect of consistent windstress patterns in austral fall and spring.

Species of coccoliths and foraminifera dominant at both trap positions are representative of open-ocean conditions, with coastal-upwelling related species as accompanying components. As above shown, this pattern remains unchanged almost throughout the year. The coccolith community at the WR site was domi-

Table 2

Comparative summary on an annual basis of the major components of the particle flux and organism assemblages at two pelagic mooring sites in the Benguela Upwelling System: the NU site (this study) and the WR site $\left(20^{\circ} 03^{\prime} \mathrm{S}, 09^{\circ} 09^{\prime} \mathrm{E}\right.$, Walvis Ridge, March $\left.1989-\mathrm{February} 1990\right)$

\begin{tabular}{|c|c|c|}
\hline & NU site $\left(29^{\circ} 12^{\prime} \mathrm{S}, 13^{\circ} 07^{\prime} \mathrm{E}\right.$; trap depth: $\left.2516 \mathrm{~m}\right)$ & WR site $\left(20^{\circ} 03^{\prime} \mathrm{S}, 09^{\circ} 09^{\prime} \mathrm{E}\right.$; trap depth: $\left.599 \mathrm{~m}\right)$ \\
\hline \multicolumn{3}{|c|}{ Yearly fluxes (bulk components, $\mathrm{g} \mathrm{m}^{-2}$ year $^{-1}$ ) } \\
\hline Total mass & 30.7 & $43.9^{\mathrm{a}}$ \\
\hline Calcium carbonate & $21.3(69.4 \%)$ & $27.5(62.5 \%)^{\mathrm{a}}$ \\
\hline Lithogenics & $4.4(14.3 \%)$ & $3.4(7.8 \%)^{\mathrm{a}}$ \\
\hline Biogenic opal & $2.9(9.4 \%)$ & $3.9(8.8 \%)^{\mathrm{a}}$ \\
\hline Organic carbon & $1.6(5.2 \%)$ & $4.6(10.5 \%)^{\mathrm{a}}$ \\
\hline \multicolumn{3}{|l|}{ Organisms } \\
\hline Coccoliths & $1.6 \times 10^{12} \mathrm{~m}^{-2}$ year $^{-1}$ & $1.1 \times 10^{11} \mathrm{~m}^{-2}$ year $^{-1 \mathrm{~b}}$ \\
\hline Foraminifera & $1.3 \times 10^{5}$ individuals $\mathrm{m}^{-2}$ year $^{-1}$ & $3.4 \times 10^{6}$ individuals $\mathrm{m}^{-2}$ year $^{-1 \mathrm{c}}$ \\
\hline Diatoms & $1.5 \times 10^{8}$ valves $^{-2}$ year $^{-1}$ & $20.0 \times 10^{8}$ valves $\mathrm{m}^{-2}$ year $^{-1 \mathrm{~d}, \mathrm{e}}$ \\
\hline $\begin{array}{l}\text { Season of highest total } \\
\text { mass flux }\end{array}$ & Summer and winter & Fall and spring ${ }^{\mathrm{a}-\mathrm{e}}$ \\
\hline \multicolumn{3}{|l|}{ Flora composition } \\
\hline Coccoliths & $\begin{array}{l}\text { E. huxleyi dominates throughout the year; } \\
\text { G. flabellatus, G. ericsonii, C. leptoporus } \\
\text { and } F \text {. profunda as secondary contributors }\end{array}$ & $\begin{array}{l}\text { E. huxleyi dominates throughout the year; } \\
\text { C. leptoporus, G. oceanica, and U. sibogae } \\
\text { as subordinate species }{ }^{\mathrm{b}}\end{array}$ \\
\hline Diatoms & $\begin{array}{l}\text { Assemblage dominated by the pelagic } F \text {. doliolus; } \\
\text { higher contribution of coastal species in summer }\end{array}$ & $\begin{array}{l}\text { Mainly neritic species, accompanied by oceanic, } \\
\text { tropical and subtropical planktonic diatoms } \mathrm{d}, \mathrm{e}\end{array}$ \\
\hline \multicolumn{3}{|l|}{ Faunal composition } \\
\hline Foraminifera & $\begin{array}{l}\text { G. inflata is the most important component } \\
\text { year-round; secondary contributions by } \\
\text { dextral } N . \text { pachyderma, G. bulloides } \\
\text { and } O \text {. universa }\end{array}$ & $\begin{array}{l}\text { G. inflata and } N . \text { dutertrei dominate the flux, } \\
\text { with secondary contributions by dextral } \\
N . \text { pachyderma, G. bulloides and } O \text {. universa }\end{array}$ \\
\hline
\end{tabular}

For the latter, the flux of bulk components (expressed as $\mathrm{g} \mathrm{m}^{-2}$ year $^{-1}$ ) was taken from Fischer and Wefer (1996). The annual mean relative contribution is given in brackets. Data for organism fluxes and assemblage composition were taken from Čepek (1996), Treppke et al., (1996), Romero et al. (1999) and Donner (unpublished data).

${ }^{\text {a }}$ From Wefer and Fischer (1993) and Fischer and Wefer (1996).

${ }^{\mathrm{b}}$ From Čepek (1996).

${ }^{\mathrm{c}}$ From Donner (unpublished data).

${ }^{\mathrm{d}}$ From Treppke et al. (1996).

${ }^{\text {e }}$ From Romero et al. (1999). 
nated by the cosmopolitan E. huxleyi (52-74\%), with minor contributions by $G$. oceanica, C. leptoporus and U. sibogae (Čepek, 1996; Baumann et al., 1999). The flux of coccoliths closely followed that of the total mass and calcium carbonate, with highest abundances during periods of more intense coastal upwelling in late austral fall and early spring in the northern BUS (Čepek, 1996). During the period of highest particle export, the foraminifer $G$. inflata clearly dominated the assemblage at the WR position, accompanied by $N$. dutertrei (d'Orbigny), dextral N. pachyderma and G. bulloides as subordinate components (Donner, unpublished data). The occurrence of coastal water-associated diatoms at the WR site indicates offshore influence from the coastal domain through the Cape Frio chlorophyll filament (Treppke et al., 1996; Romero et al., 1999). In contrast with the NU site, diatoms typical for oceanic waters played a subordinate role at the WR mooring almost throughout the year.

Coccolith and coccosphere fluxes at the NU site are qualitatively similar to those recorded by a highresolution time-series experiment at a shelf-edge site off Walvis Bay between September 1989 and January 1990 (Giraudeau et al., 2000). Once again interannual variability should be considered, but it is interesting to see that, at least for the months in comparison, the free coccolith fraction was one order of magnitude higher at the NU site. Upwelled waters at the near-shore trap site off Walvis Bay extend up to the mooring location almost throughout the experiment and determine the assemblage composition (Giraudeau et al., 2000). E. huxleyi overwhelmingly dominates both coccolith and coccosphere assemblages along the southern part of the BUS. Subordinate contributors were Helicospheri carteri (Wallich) Kamptnert, G. oceanica, C. leptoporus, G. muellerae Bréhéret and Coronosphaera mediterranea (Lohmann) Gaarder. As expected, the composition of the foraminifera assemblage at the near-shore trap location off Walvis Bay at $23^{\circ} \mathrm{S}$ was dominated by the right-coiled $N$. pachyderma and $G$. bulloides, preferentially distributed within a mixed domain of mature upwelled waters, and the opportunistic species Turborotalia quinqueloba (Natland).

\subsection{Implications for paleoreconstructions}

In order to use the calcareous and siliceous microfossil record for the interpretation of past oceano- graphic conditions in the BUS, it is necessary to understand the nature of present-day occurrence of dominant organisms. To make use of these data, we need to assess the accuracy with which the fossil record reproduces the original living assemblage. The taxonomic composition and distribution of the sediment trap associations at the NU site is a first step in order to interpret the microfossil signal. Hence, our observations are of relevance for paleoceanographers who need to identify and calibrate climate-ocean proxies for the sedimentary record.

For the calcareous organisms, a good agreement exist between water column and surface sediment assemblages. As in NU sediment trap samples, the coccolithophorid association found in shelf sediments off Namibia is dominated by E. huxleyi, with $C$. leptoporus, G. oceanica and Umbilicosphaera sibogae (Weber-Van Bosse) Garrder as secondary components (Baumann et al., 1999). E. huxleyii has been characterized as the only species observed in high abundances across the main hydrographical boundaries from coastal upwelling to the oceanic domain in the southern BUS (Giraudeau and Bailey, 1995). Its worldwide geographical distribution both in the water column and in the surface sediments reflects its broad range of ecological tolerance (Baumann et al., 1999). Among the planktonic foraminifera, G. inflata and N. pachyderma (right) dominate the microfossil association in pelagic surface sediments of the Cape Basin, with $G$. bulloides and $O$. universa as accompanying species. Globorotalia inflata, often a dominant component in temperate waters, shows its highest percentages in core top sediments around $40^{\circ} \mathrm{S}$ in the South Atlantic (Kemle-von Mücke and Hemleben, 1999). Increasing numbers of $G$. bulloides in surface sediments south of $30^{\circ} \mathrm{S}$ has been interpreted as reflecting its preference for fertile transitional and subpolar waters (Kemle-von Mücke and Oberhänsli, 1999), and the lesser influence of coastal upwelled waters into the pelagic Cape Basin (Kemle-von Mücke and Hemleben, 1999).

A good agreement exists between the biocoenotic and the thanatocoenotic diatom community in the Cape Basin. On studying the fossil diatom populations preserved in core top sediments off SW Africa, Romero et al. (1999) observed that $F$. doliolus and T. nitzschioides var. nitzschioides are main components of the diatom thanatocoenosis. Schuette and Schrader (1981) found A. octonarius and several meroplank- 
tonic Coscinodiscus spp. to be secondary components of the preserved diatom community in near-shore areas off South West Africa. F. doliolus, a common component of warm-water diatom floras (Romero et al., 1999, 2000, 2001), appears usually well preserved in pelagic sediments in midlatitudes areas. T. nitzschioides var. nitzschioides is a typical component of midlatitudes coastal diatom assemblages (Romero et al., 1999, 2001), and has been reported in bloom concentrations in and near Walvis Bay (Schuette and Schrader, 1981). In sediments underlying the NU trap site, representatives of a tropical/subtropical diatom flora, such as species of Azpetia, Alveus marinus, $T$. oestrupii var. oestrupii and T. nitzschioides var. parva, have been reported (Romero et al., 1999, 2000). All of these species were present in the NU trap samples Table A2, some of them as secondary components of the diatom assemblage. As for the sediment trap, the mixture of diatoms with different ecological affinities preserved in surface sediments of the Cape Basin mirrors the complicated hydrology of this transitional region of interplay between oceanic and coastal conditions (Romero et al., 1999). In summary, our sediment trap observations confirm that the microfossil signal preserved in near-shore and pelagic areas off SW Africa are in good agreement with the main organisms thriving in overlying waters. Hence, coccolithophorids, planktonic foraminifera and diatoms can be used as reliable indicators of hydrographic conditions in the Cape Basin.

\section{Conclusions}

A central objective of our work was to determine whether and when offshore spreading of nutrient-rich filaments influence the export of particulates and organisms in a pelagic area in the Benguela Upwelling System. To answer this question, we follow the year-round dynamics of flux of particulates, and the quantitative and qualitative variations in the coccolithophorid, planktonic foraminifera and diatom assemblages. We demonstrate that the biogenic sedimentation at a pelagic trap site off SW Africa is mostly under the influence of the moderate productivity regime of the Subtropical South Atlantic Gyre, with some influence of the Namaqua coastal upwelling cell.

The flux of bulk components mostly shows bimodal seasonality with major peaks in austral summer and winter, and moderate to low export in austral fall and spring. The calcium carbonate fraction dominates the export throughout the year, and is mainly delivered by planktonic foraminifera and coccolithophorids. Lithogenics, biogenic opal, and organic carbon are secondary components. The $\delta^{15} \mathrm{~N}$ isotopic signal of particulate matter correlates well with the total mass flux in austral summer and fall, but appears negatively correlated during austral winter and spring.

Significant seasonal differences in the floral and faunal populations trapped at the NU site support the usefulness of these data as sensitive indicators of water masses and main productivity regimes (oceanic and upwelling) in the central pelagic Benguela Current System. The richly composed populations of coccolithophorids, planktonic foraminifera, and diatoms quickly response to the dominant hydrographic conditions at the NU mooring site, and offer reliable clues in order to understand the prevailing hydrographic conditions. The coccolithophorids C. leptoporus and the diatoms Azpeitia spp., A. curvatulus and C. radiatus can be characterized as the "summer association," accompanied by the coccolithophorids F. profunda, G. flabellatus (both representatives of LPZ) and the planktonic foraminifera G. inflata. The winter association is predominantly composed by the coccolithophorid E. huxleyi, the planktonic foraminifera $G$. inflata and G. bulloides and the diatoms $F$. doliolus and $A$. octonarius. The planktonic foraminifera N. pachyderma right, O. universa and G. ruber white builds a seasonally "mixed" group. The continuous sediment trap record gained at the NU site provides useful information on seasonal dynamics of the export signal and will help to interpret the paleoceanographical signal preserved in the BUS.

\section{Acknowledgements}

We are very grateful to J. Giraudeau and C. Lange who read a first draft. The final version greatly benefited from thoughtful reviews by three anonymous referees. Thanks are also due to officers and crew of the RV Meteor for competent assistance in recovery of the mooring array. M. Klann is gratefully acknowledged for laboratory measurements. This research was funded by the Deutsche Forschungsgemeinschaft (Sonderforschungsbereich 261 at the University Bremen, Contribution no. 343). 


\section{Appendix A}

Table A1

Daily flux of total mass, calcium carbonate, lithogenics, biogenic opal, organic carbon, $\delta^{15} \mathrm{~N}$ isotopic signal, coccoliths, coccospheres, foraminifera and diatom gained at the $\mathrm{NU}$ mooring site $\left(29^{\circ} 12^{\prime} \mathrm{S}, 13^{\circ} 07^{\prime} \mathrm{E}\right)$ in the Benguela Upwelling System from January 1992 through January 1993

\begin{tabular}{|c|c|c|c|c|c|c|c|c|c|c|c|c|c|c|c|}
\hline \multirow{2}{*}{$\begin{array}{l}\text { Sample } \\
\text { no. }\end{array}$} & \multirow{2}{*}{$\begin{array}{l}\text { Trap cup } \\
\text { (opened) }\end{array}$} & \multicolumn{5}{|c|}{ Bulk components: fluxes $\left(\mathrm{mg} \mathrm{m}^{-2}\right.$ day $\left.^{-1}\right)$} & \multicolumn{4}{|c|}{ Relative contribution $(\%)$} & \multirow{2}{*}{$\begin{array}{l}\frac{\mathrm{N} \text { isotope }}{\delta^{15} \mathrm{~N}} \\
(\% \circ)\end{array}$} & \multicolumn{4}{|l|}{ Organisms } \\
\hline & & $\begin{array}{l}\text { Total } \\
\text { mass }\end{array}$ & $\begin{array}{l}\text { Calcium } \\
\text { carbonate }\end{array}$ & Lithogenics & $\begin{array}{l}\text { Biogenic } \\
\text { opal }\end{array}$ & $\begin{array}{l}\text { Organic } \\
\text { carbon }\end{array}$ & $\begin{array}{l}\text { Calcium } \\
\text { carbonate }\end{array}$ & Lithogenics & $\begin{array}{l}\text { Biogenic } \\
\text { opal }\end{array}$ & $\begin{array}{l}\text { Organic } \\
\text { carbon }\end{array}$ & & $\begin{array}{l}\text { Coccoliths } \\
\left(10^{8} \mathrm{~m}^{-2}\right. \\
\left.\text { day }^{-1}\right)\end{array}$ & $\begin{array}{l}\text { Coccospheres } \\
\left(10^{6} \mathrm{~m}^{-2}\right. \\
\left.\text { day }^{-1}\right)\end{array}$ & $\begin{array}{l}\text { Foraminifera } \\
(>150 \mu \mathrm{m}) \\
\text { (individual } \mathrm{m}^{-2} \\
\text { day }^{-1} \text { ) }\end{array}$ & $\begin{array}{l}\text { Diatoms } \\
\left(\text { valves } \times 10^{5}\right. \\
\left.\mathrm{m}^{2} \text { day }^{-1}\right)\end{array}$ \\
\hline 1 & 01.20 .92 & 73.5 & 54.0 & 7.9 & 3.1 & 4.2 & 73.4 & 10.8 & 4.3 & 5.8 & 6.8 & 8.5 & 0.0 & 298 & 3.3 \\
\hline 2 & 02.08 .92 & 203.6 & 139.3 & 35.3 & 7.2 & 10.9 & 68.4 & 17.3 & 3.5 & 5.4 & 7.3 & 100.9 & 0.0 & 1325 & 9.9 \\
\hline 3 & 02.27 .92 & 143.2 & 97.1 & 24.0 & 7.0 & 7.6 & 67.8 & 16.7 & 4.9 & 5.3 & 6.5 & 63.9 & 11.9 & 253 & 4.7 \\
\hline 4 & 03.17 .92 & 88.0 & 60.8 & 13.5 & 4.2 & 4.8 & 69.1 & 15.3 & 4.7 & 5.4 & 6.4 & 27.2 & 0.0 & 140 & 2.1 \\
\hline 6 & 04.24 .92 & 48.2 & 33.3 & 7.8 & 2.3 & 2.4 & 69.1 & 16.2 & 4.9 & 4.9 & 6.3 & 21.7 & 0.0 & 143 & 1.3 \\
\hline 7 & 05.13 .92 & 61.7 & 46.8 & 4.5 & 3.1 & 3.7 & 75.9 & 7.3 & 5.0 & 5.9 & 5.9 & 28.6 & 5.2 & 362 & 1.3 \\
\hline 8 & 06.01 .92 & 49.9 & 36.8 & 5.4 & 2.9 & 2.4 & 73.7 & 10.9 & 5.9 & 4.8 & 6.5 & 18.2 & 3.3 & 160 & 1.3 \\
\hline 9 & 06.20 .92 & 54.9 & 41.2 & 5.3 & 3.5 & 2.5 & 75.0 & 9.6 & 6.3 & 4.5 & 6.3 & 25.3 & 4.7 & 115 & 1.7 \\
\hline 10 & 07.09 .92 & 39.8 & 29.2 & 4.8 & 2.2 & 1.9 & 73.2 & 12.0 & 5.5 & 4.6 & 6.1 & 19.0 & 3.6 & 130 & 1.3 \\
\hline 11 & 07.28 .92 & 168.8 & 124.7 & 19.6 & 10.9 & 6.8 & 73.8 & 11.6 & 6.5 & 4.0 & 4.4 & 71.8 & 0.0 & 729 & 10.1 \\
\hline 12 & 08.16 .92 & 159.7 & 112.6 & 21.9 & 10.6 & 7.3 & 70.5 & 13.7 & 6.7 & 4.6 & 4.3 & 234.6 & 42.3 & 2075 & 19.3 \\
\hline 13 & 09.04 .92 & 102.6 & 71.4 & 12.3 & 9.9 & 4.5 & 69.6 & 12.0 & 9.7 & 4.4 & 5.0 & 64.2 & 0.0 & 450 & 7.1 \\
\hline 16 & 10.31 .92 & 98.6 & 63.5 & 16.1 & 8.6 & 5.1 & 64.5 & 16.4 & 8.7 & 5.2 & 6.3 & 43.0 & 7.7 & 261 & 4.1 \\
\hline 17 & 11.19 .92 & 86.1 & 52.9 & 17.1 & 6.1 & 5.0 & 61.5 & 19.9 & 7.1 & 5.8 & 6.4 & 14.8 & 2.8 & 190 & 3.8 \\
\hline 18 & 12.08 .92 & 49.9 & 33.3 & 7.1 & 4.6 & 2.5 & 66.7 & 14.2 & 9.2 & 5.0 & 6.7 & 22.1 & 0.0 & 66 & 1.2 \\
\hline 19 & 12.27 .92 & 34.7 & 22.4 & 4.6 & 2.5 & 2.6 & 64.4 & 13.4 & 7.2 & 7.5 & 8.3 & 23.6 & 17.1 & 34 & 0.8 \\
\hline 20 & 01.15 .93 & 12.3 & 8.5 & 1.6 & 0.6 & 0.8 & 69.4 & 13.1 & 4.7 & 6.4 & 7.2 & 2.9 & 0.0 & 26 & 0.1 \\
\hline
\end{tabular}

foraminifera, individuals; diatoms, valves $\times 10^{5} \mathrm{~m}^{-2}$ day ${ }^{-1}$. In addition, the relative contribution (\%) of calcium carbonate, lithogenics, biogenic opal and organic carbon is also given. 
Table A2

Taxonomy: The following list presents all the species, varieties or formae of coccolithophorids (Prymnesiophyceae), planktonic foraminifera (Foraminifera) and diatoms (Bacillariophyceae) found in sediment trap samples at the NU mooring site in the central Benguela Upwelling System from January 1992 through January 1993

Coccolithophorids

Acanthoica quattrospina Lohman 1903

Acanthoica spp.

Anacanthoica acanthos (Schiller 1925)

Deflandre 1952

Algirosphaera oriza Schlauder 1945

Alisphaera unicornis Okada and McIntyre 1977

Alisphaera spp. Heimdal 1973

Alveosphaera spp. Jordan and Young 1990

Anoplosolenia brasiliensis (Lohmann 1919)

Deflandre 1952

Calcidiscus leptoporus f. leptoporus (Murray

and Blackman 1898) Loeblich and Tappan 1978

Calciopappus rigidus Heimdal 1981

Calciosolenia murrayi Gran 1912

Calyptrolithina wettsteinii (Kamptner 1937)

Kleijne 1991

Calyptrolithophora papillifera (Halldal 1953)

Heimdal 1980

Cricosphaera quadrilaminata Okada and

McIntyre 1977

Ceratolithus cristatus var. cristatus Kamptner 1950

Coccolithus pelagicus $\mathrm{f}$. pelagicus

(Wallich 1877) Schiller 1930

Coronosphaera mediterranea (Lohman 1902)

Gaarder 1977

Discosphaera tubifera

(Murran and Blackman 1898) Ostenfeld 1900

Emiliana huxleyi var. huxleyi (Lohman 1902)

Hay and Mohler 1967

Florisphaera profunda var. profunda (Okada and Honjo 1973) Okada and McIntyre 1977

Gephirocapsa ericsonii McIntyre and Bé 1967

Gephirocapsa muellerae Chamberlain 1993

Gephirocapsa oceanica Kamptner 1943

Gephirocapsa ornata Heimdal 1973

Gladiolithus flabellatus (Haldall and Markali)

Jordan and Chamberlain 1993

Hayaster perplexus

(Bramlette and Riedel 1954) Bukry 1973

Helicosphaera pavimentum Okada and

McIntyre 1977

Helicosphaera carterii var. carterii

(Wallich 1877) Kamptner 1954

Michaelsarsia elegans (Gran 1912) emend.

Manton et al. 1984

Michaelsarsia spp. (Gran 1912) emend.

Manton et al. 1984

Neosphaera coccolithomorpha Lecal-Schlauder 1950
Table A2 (continued)

Oolithus fragilis var. fragilis (Lohmann 1912)

Martini and Müller 1972

Ophiaster reductus Manton and Oates 1983

Ophiaster spp. Gran 1912 emend. Manton and

Oates 1983

Pontosphaera spp. Lohmann 1902

Reticulofenestrata spp. Hay, Mohler and Wade 1966

Rhabdosphaera clavigera var. clavigera Murray and Blackmann 1898

Rhabdosphaera xiphos (Deflandre and Fert

1954) Norris 1984

Syracolithus catilliferus (Kamptner 1937)

Deflandre 1952

Syracosphaera anthos (Lohmann 1912) Jordan and Young 1990

Syracosphaera apsteinii f. apsteinii Lohmann 1902 Syracosphaera borealis Okada and McIntyre 1977 Syracosphaera corolla Lecal 1966

Syracosphaera corrugis Okada and McIntyre 1977

Syracosphaera exigua Okada and McIntyre 1977

Syracosphaera epigrosa Okada and McIntyre 1977

Syracosphaera halldalii f. haldalii Gaarder 1971

Syracosphaera histrica Kamptner 1941

Syracosphaera lamina Lecal-Schlauder 1951

Syracosphaera molischii Schiller 1925

Syracosphaera nana (Kamptner 1941) Okada and McIntyre 1977

Syracosphaera nodosa Kamptner 1941

Syracosphaera orbiculus Okada and McIntyre 1977

Syracosphaera prolongata Gran 1912 ex

Lohmann 1913

Syracosphaera pulchra Lohmann 1902

Syracosphaera rotula Okada and McIntyre 1977

Syracosphaera spp. Lohmann 1902

Umbellosphaera irregularis Paasche 1955

Umbellosphaera tenuis (Kamptner 1937)

Paasche 1955

Umbilocosphaera hulburtiana Gaarder 1970

Umbilocosphaera sibogae var. sibogae

(Weber-Van Bosse 1901) Gaarder 1970

Foraminifera

Globigerina bulloides d'Orbigny 1826

Globigerinoides ruber d'Orbigny 1839

Globigerinoides sacculifer Brady 1877

Globorotalia inflata d'Orbigny 1839

Globorotalia truncatulinoides d'Orbigny 1839

Globorotalia hirsuta d'Orbigny 1839

Globorotalia scitula Brady 1882

Globigerinella calida Parker 1962

Globigerinella siphonifera d'Orbigny 1839

Neogloboquadrina dutertei d'Orbigny 1839

Neogloboquadrina pachyderma Ehrenberg 1861

Orbulina universa d'Orbigny 1839 
Table A2 (continued)

\section{Diatoms}

Actinocyclus curvatulus Janisch 1874

Actinocyclus elongatus Grunow 1881

Actinocyclus exiguus G. Fryxell and Semina 1981

Actinocyclus octonarius Ehrenberg 1838

Aptinoptychus senarius (Ehrenberg) Ehrenberg 1838

Aptinoptychus vulgaris Schumann 1867

Alveus marinus (Grunow) Kaczmarska and G. Fryxell 1996

Amphora ostrearia Brébisson 1849

Amphora spp.

Asterolampra marylandica Ehrenberg 1844

Asteromphalus arachne Brébisson 1857

Asteromphalus cleveanus Grunow 1874

Asteromphalus elegans Greville 1859

Asteromphalus flabellatus (Brébisson) Greville 1859

Aulacoseira islandica (O. Müller) Simonsen 1906

Azpeitia africana (Janisch ex Schmidt) G. Fryxell

and T.P. Watkins 1986

Azpeitia neocrenulata (Van Landingham) G.

Fryxell and T.P. Watkins 1986

Azpeitia nodulifera (A. Schmidt) G. Fryxell and

T.P. Watkins 1986

Azpeitia tabularis (Grunow) G. Fryxell and T.P. Watkins 1986

Bacteriastrum elongatum Cleve 1897

Bacteriastrum furcatum Shadbolt 1854

Bacteriastrum hyalinum Lauder 1864

Biddulphia alternans (J.W. Bailey) Van Heurck

Catenula pelagica Mereschkowsky

Chaetoceros didymus Ehrenberg 1845

Chaetoceros messanensis Castracane 1875

Resting spore (RS) Chaetoceros affinis Lauder 1864

RS Chaetoceros debilis Cleve

RS Chaetoceros diadema (Ehrenberg) Gran 1897

RS Chaetoceros radicans Schütt 1895

RS Chaetoceros socialis Lauder 1864

RS Chaetoceros vanheurckii Gran 1900

RS Chaetoceros spp.

Coscinodiscus argus Ehrenberg 1839

Coscinodiscus centralis Ehrenberg 1839

Coscinodiscus oculus-iridis Ehrenberg 1854

Coscinodiscus radiatus Ehrenberg 1841

Cymatosira lorenziana Grunow 1862

Delphineis karstenii (Boden) G. Fryxell 1878

Delphineis surirella (Ehrenberg) Andrews

Diploneis bombus Ehrenberg 1844

Diploneis papula var. constricta Hustedt 1927

Fragilariopsis doliolus (Wallich) Medlin and Sims 1996

Fragilariopsis kerguelensis (O'Meara) Hustedt 1952

Hantzschia amphyoxis (Ehrenberg) Grunow 1880

Hemidiscus cuneiformis Wallich 1860

Lioloma elongatum (Grunow) Hasle 1996

Luticola mutica f. mutica Kützing 1844

Nitzschia bicapitata Cleve 1901

Nitzschia braarudii Hasle 1960

Nitzschia capuluspalae Simonsen 1974
Table A2 (continued)

Nitzschia dietrichii Simonsen 1974

Nitzschia interruptestriata (Heiden) Simonsen 1974

Nitzschia kolaczekii Grunow 1877

Nitzschia sicula (Castracane) Hustedt 1958

Nitzschia sicula aff. $N$. cf. sicula

Planktoniella sol (Wallich) Schütt 1860

Pleurosigma directum Grunow 1880

Pseudo-nitzschia pungens (Grunow ex Cleve) Hasle 1965

Pseudosolenia calvar-avis (Schultze) Sundström 1986

Pseudostaurosira brevistriata (Grunow) Williams and Round 1987

Pseudotriceratium punctatum (Wallich) Simonsen 1974

Rhizosolenia bergonii H. Peragallo 1892

Rhizosolenia pungens Cleve-Euler 1937

Rhizosolenia styliformis Brightwell 1858

Roperia tesselata (Roper) Grunow 1880

Stellarima stellaris (Roper) Hasle and Sims 1986

Thalassionema bacillare (Heiden) Kolbe 1955

Thalassionema aff. $T$. cf bacillare 1

Thalassionema aff. T. cf bacillare 2

Thalassionema frauenfeldii (Grunow) Hallegraeff 1986

Thalassionema nitzschioides var. nitzschioides

(Grunow) Van Heurck

Thalassionema nitzschioides f. capitulata

(Castracane) Moreno-Ruiz 1996

Thalassionema nitzschioides var. inflata Kolbe 1928

Thalassionema nitzschiodes var. parva

(Heiden) Moreno-Ruiz 1996

Thalassiora anguste-lineata (A. Schmidt) G. Fryxell and

Hasle 1977

Thalassiora bioculata (Grunow) Ostenfeld 1903

Thalassiora eccentrica (Ehrenberg) Cleve 1904

Thalassiora elsayedii G. Fryxell 1975

Thalassiora endoseriata Hasle and Fryxell 1977

Thalassiora ferelineata Hasle and Fryxell 1977

Thalassiora leptopus (Grunow) Hasle and Fryxell 1977

Thalassiora lineata Josué 1968

Thalassiora mendiolana Hasle and Heimdal 1970

Thalassiora nanolineata (Mann) G. Fryxell and Hasle 1977

Thalassiora oestrupii var. oestrupii (Ostenfeld) Hasle 1972

Thalassiora oestrupii var. venrickae G. Fryxell and Hasle 1972

Thalassiora pacifica Gran and Angst 1931

Thalassiora poro-irregulata Hasle and Heimdal 1970

Thalassiora rotula Meunier 1910

Thalassiora sacketii f. sacketii G. Fryxell 1977

Thalassiora symmetrica G. Fryxell and Hasle 1972

Thalassiora symmetrica G. Fryxell and Hasle 1972

Trachyneis aspera Cleve 1894

Each species is followed by the author's name and year of description. In a few cases we were unable to identify the taxon to the species level. If this taxon was found repeatedly the generic name was used, followed by "spp." 
Table A3

Varimax loadings matrix (rotation: varimax normalized). Factor scores for analysis on sediment trap samples using taxa with abundances higher than $1.5 \%$ of total assemblage in at least one sample. Shadings highlight dominant species or group of species within each factor (loadings $>0.700)$

\begin{tabular}{llcccc}
\hline Organisms & Species or group of species & Factor 1 & Factor 2 & Factor 3 & Factor 4 \\
\hline Coccolith. & E. huxleyi & 0.548 & 0.042 & 0.790 & 0.037 \\
& C. leptoporus & 0.739 & -0.018 & 0.569 & 0.162 \\
& F. profunda & 0.837 & 0.097 & 0.394 & -0.139 \\
Glanktonic Foramanif. & G. flabellatus & 0.889 & -0.045 & 0.087 & -0.230 \\
& G. inflata & 0.613 & 0.197 & 0.720 & 0.048 \\
& N. pachyderma & 0.324 & 0.750 & 0.275 & 0.360 \\
& G. bulloides & -0.209 & 0.526 & 0.707 & 0.261 \\
& O. universa & 0.134 & 0.939 & 0.155 & -0.086 \\
Diatoms & G. ruber white & -0.076 & 0.787 & -0.238 & -0.389 \\
& F. doliolus & 0.343 & 0.004 & 0.913 & 0.037 \\
& Azpeitia spp. & 0.858 & 0.212 & 0.134 & 0.319 \\
& T. nitzschioides var. inflata & 0.033 & -0.108 & 0.051 & 0.849 \\
\hline & A. curvatulus & 0.872 & 0.100 & 0.300 & 0.174 \\
& A. octonarius & 0.614 & -0.027 & 0.733 & 0.111 \\
& C. radiatus & 0.710 & 0.112 & 0.410 & 0.476 \\
\hline
\end{tabular}

\section{References}

Altabet, M.A., Deuser, W.G., Honjo, S., Stienen, C., 1991. Seasonal and depth-related changes in the source of sinking particles in the North Atlantic. Nature 354, 136-139.

Andruleit, H., 1996. A filtration technique for quantitative studies of coccoliths. Micropaleontology 42, 403-406.

Antoine, D., André, J.-M., Morel, A., 1996. Oceanic primary production: 2. Estimation at a global scale from satellite (Coastal Color Zonal Scanner) chlorophyll. Glob. Biogeochem. Cycles 10, 57-69.

Baumann, K.-H., Čepek, M., Kinkel, H., 1999. Coccolithophores as indicators of ocean water masses, surface-water temperature, and paleoproductivity - examples from the South Atlantic. In: Fischer, G., Wefer, G. (Eds.), The South Atlantic Ocean, Present and Past Circulation. Springer-Verlag, Berlin, pp. 117-144.

Berger, W.H., 1989. Global maps of ocean productivity. In: Berger, W.H., Smetacek, V.S., Wefer, G. (Eds.), Productivity in the Ocean: Present and Past. Wiley, Chichester, pp. 429-455.

Čepek, M., 1996. Zeitliche und räumliche Variationen von Coccolithophoriden-Gemeinschaften im subtropischen Ost-Atlantik: Untersuchungen an Plankton, Sinkstoffen und Sedimenten. Berichte, Fachbereich Geowissenschaften, Universität Bremen, Nr. 86, Bremen, $156 \mathrm{pp}$.

DeMaster, D.J., 1981. The supply and accumulation of silica in the marine environment. Geochim. Cosmochim. Acta 45, $1715-1732$.

Fischer, G., Wefer, G., 1991. Sampling, preparation and analysis of marine particulate matter. In: Hurd, D.C., Spencer, D.W. (Eds.), The Analysis and Characterization of Marine Particles. Geophysical Monograph, vol. 63. American Geophysical Union, Washington, DC, pp. 391-397.

Fischer, G., Wefer, G., 1996. Long-term observation of particle flux in the eastern Atlantic: seasonality, changes of flux with depth and comparison with the sediment record. In: Wefer, G., Berger, W.H., Siedler, G., Webb, D.J. (Eds.), The South Atlantic Ocean, Present and Past Circulation. Springer-Verlag, Berlin, pp. 325-344.

Giraudeau, J., 1992. Distribution of recent nannofossil beneath the Benguela system: southwest African continental margin. Mar. Geol. 108, 219-237.

Giraudeau, J., 1993. Planktonic foramiferal assemblages in surface sediments from the southwest African continental margin. Mar. Geol. 110, 47-62.

Giraudeau, J., Bailey, G.W., 1995. Spatial dynamics of coccolithophore communities during an upwelling event in the Southern Benguela system. Cont. Shelf Res. 15, 1825-1852.

Giraudeau, J., Rogers, J., 1994. Phytoplankton biomass and seasurface temperature estimates from sea-bed distribution of nannofossils and planktonic foraminifera in the Benguela upwelling system. Micropaleontology 40, 275-285.

Giraudeau, J., Bailey, G.W., Pujol, C., 2000. A high resolution time series analysis of particle fluxes in the Northern Benguela System: carbonate record of changes in biogenic production and particle transfer processes. Deep-Sea Res., Part 2 47, 1999-2028.

Holmes, M.E., Eichner, C., Struck, U., Wefer, G., 1999. Reconstruction of ocean nitrate utilization using stable nitrogen isotope in sinking particles and sediments. In: Fischer, G., Wefer, G. (Eds.), Use of Proxies in Paleoceanography, Examples from the South Atlantic. Springer-Verlag, Berlin, pp. 447-468.

Holmes, M.E., Lavik, G., Fischer, G., Segl, M., Ruhland, G., Wefer, G., 2002. Seasonal variability of $\delta^{15} \mathrm{~N}$ in sinking particles in the Benguela upwelling system. Deep-Sea Res., Part 1 49, 377-394.

Kemle-von Mücke, S., Hemleben, C., 1999. Foraminifera. In: Boltovskoy, D. (Ed.), South Atlantic Zooplankton, vol. 1. Backhuys Publishers, Leiden, pp. 43-73.

Kemle-von Mücke, S., Oberhänsli, C., 1999. The distribution of 
living planktonic foraminifera in relation to Southeast Atlantic oceanography. In: Fischer, G., Wefer, G. (Eds.), Use of Proxies in Paleoceanography, Examples from the South Atlantic. Springer-Verlag, Berlin, pp. 91-115.

Lange, C.B., Berger, W.H., Lin, H.-L., Wefer, G.Shipboard Scientific Party Leg 175, 1999. The early Matuyama Diatom Maximum off SW Africa, Benguela Current System (ODP Leg 175). Mar. Geol. 161, 93-114.

Lutjeharms, J.R.E., Meeuwis, J.M., 1987. The extent and variability of South-east Atlantic upwelling. S. Afr. J. Mar. Sci. 5, 51-62.

Lutjeharms, J.R.E., Stockton, P.L., 1987. Kinematics of the upwelling front off Southern Africa. S. Afr. J. Mar. Sci. 5, 35-49.

Lutjeharms, J.R.E., Shillington, F.A., Ducombe Rae, C.M., 1991. Observations of extreme upwelling filaments in the South East Atlantic Ocean. Science 253, 774-776.

Müller, P., Schneider, R., 1993. An automated leaching method for the determination of opal in sediments and particulate matter. Deep-Sea Res. 40, 425-444.

Müller, P.J., Čepek, M., Ruhland, G., Schneider, R., 1997. Alkenone and coccolithophorid species changes in late Quaternary sediments from the Walvis Ridge: implications for the alkenone paleotemperature record. Palaeogeogr. Palaeoclimatol. Palaeoecol. 135, 71-96.

Nelson, G., Hutchings, L., 1983. The Benguela upwelling area. Prog. Oceanogr. 12, 333-356.

Oberhänsli, H., Bénier, C., Meinecke, G., Schmidt, H., Schneider, R., Wefer, G., 1992. Planktic foraminifers as tracers of ocean currents in the eastern South Atlantic. Paleoceanography 7, $607-632$.

Okada, H., Honjo, S., 1973. The distribution of oceanic coccolithophorids in the Pacific. Deep-Sea Res. 20, 355-374.

Peterson, R.G., Stramma, L., 1991. Upper-level circulation in the South Atlantic Ocean. Prog. Oceanog. 26, 1-73.

Romero, O.E., Lange, C.B., Fischer, G., Treppke, U.F., Wefer, G., 1999. Variability in export production documented by downward fluxes and species composition of marine planktonic diatoms: observations from the tropical and equatorial Atlantic. In: Fischer, G., Wefer, G. (Eds.), The Use of Proxies in Paleoceanography, Examples from the South Atlantic. Springer-Verlag, Berlin, pp. $365-392$.

Romero, O.E., Fischer, G., Lange, C.B., Wefer, G., 2000. Siliceous phytoplankton of the western equatorial Atlantic: sediment traps and surface sediments. Deep-Sea Res., Part 2 47, 1939-1959.

Romero, O., Hebbeln, D., Wefer, G., 2001. Temporal and spatial distribution in export production in the SE Pacific Ocean: evi- dence from siliceous plankton fluxes and surface sediment assemblages. Deep-Sea Res., Part 1 48, 2673-2697.

Sancetta, C., Calvert, S.E., 1988. The annual cycle of sedimentation in Saanich Inlet, British Columbia: implications for the interpretation of diatom fossil assemblages. Deep-Sea Res. 35, 71-90.

Schrader, H., Gersonde, R., 1978. Diatoms and silicoflagellates. In: Zachariasse, W.J., Riedel, W.R., Sanfilippo, A., Schmidt, R.R., Brolsma, M.J., Schrader, H., Gersonde, R., Drooger, M.M., Broekman, J.A. (Eds.), Micropaleontological Counting Methods and Techniques-An Exercise on an Eight Meter Section of the Lower Pliocene of Capo Rosello, Sicily. Utrecht Micropaleontol. Bull., vol. 17, pp. 129-176.

Schuette, G., Schrader, H., 1981. Diatoms in surface sediments: a reflection of coastal upwelling. In: Richards, F.A. (Ed.), Coastal and Estuarine Sciences: I. Coastal Upwelling. American Geophysical Union, Washington, DC, pp. 372-380.

Shannon, L.V., 1985. The Benguela Ecosystem: 1. Evolution of the Benguela, physical features and processes. In: Barnes, M. (Ed.), Oceanography and Marine Biology, An Annual Review, vol. 23. University Press, Aberdeen, pp. 105-182.

Shannon, L.V., Nelson, G., 1996. The Benguela: large scale features and processes and system variability. In: Wefer, G., Berger, W.H., Siedler, G., Webb, D.J. (Eds.), The South Atlantic: Present and Past Circulation. Springer-Verlag, Berlin, pp. 163-210.

Shillington, F.A., Peterson, W.T., Hutchings, L., Probyn, T.A., Waldron, H.N., Jagenbag, J., 1990. A cool upwelling filament off Namibia, southwest Africa: preliminary measurements of physical and biological features. Deep-Sea Res. 37, 1753-1772.

Simonsen, R., 1974. The diatom plankton of the Indian Ocean Expedition of RV “Meteor" 1964-1965. Meteor-Forschungsergeb. D19, 1-66.

StatSoft, 2001. Electronic Statistics Textbook. Tulsa, OK: StatSoft. http://www.statsoft.com/textbook/stathome.html.

Treppke, U.F., Lange, C.B., Donner, B., Fischer, G., Ruhland, G., Wefer, G., 1996. Diatom and silicoflagellate fluxes at the Walvis Ridge: an environment influenced by coastal upwelling in the Benguela system. J. Mar. Res. 54, 991-1016.

Wefer, G., Fischer, G., 1993. Seasonal pattern of vertical particle flux in equatorial and coastal upwelling areas of the eastern Atlantic. Deep-Sea Res., Part 1 40, 1613-1645.

Winter, A., Jordan, R.W., Roth, P.H., 1994. Biogeography of living coccolithophores in ocean waters. In: Winter, A., Siesser, W.G. (Eds.), Coccolithophores. Cambridge Univ. Press, Cambridge, pp. $161-177$. 